\title{
The Effects of Rural Electrification on Quality of Life: A Southeast Asian Perspective
}

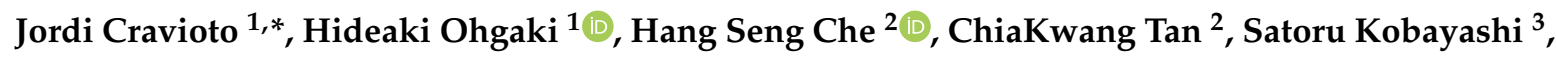 \\ Hla Toe ${ }^{4}$, Bun Long ${ }^{5}$, Eth Oudaya ${ }^{5}$, Nasrudin Abd Rahim ${ }^{2}$ and Hooman Farzeneh ${ }^{6,7(0)}$ \\ 1 Institute of Advanced Energy, Kyoto University, Gokasho, Uji, Kyoto 611-0011, Japan; \\ ohgaki.hideaki.2w@kyoto-u.ac.jp \\ 2 UM Power Energy Dedicated Advanced Centre (UMPEDAC), Higher Institution Centre of \\ Excellence-Ministry of Higher Education (HICoE-MOHE), Level 4, Wisma R\&D, University of Malaya, Jalan \\ Pantai Baharu, Kuala Lumpur 59990, Malaysia; hsche@um.edu.my (H.S.C.); cktan@um.edu.my (C.T.); \\ nasrudin@um.edu.my (N.A.R.) \\ 3 Center for Southeast Asian Studies, Kyoto University, 46 Shimoadachi-cho, Yoshida, Sakyo-ku, \\ Kyoto 606-8501, Japan; kobasa@cseas.kyoto-u.ac.jp \\ 4 Physics Department, Panglong University, Panglong 06114, Myanmar; drhlatoe@gmail.com \\ 5 Electrical \& Energy Engineering Department, Institute of Technology of Cambodia, \\ Phnom Penh 120404, Cambodia; bunlong@itc.edu.kh (B.L.); ou.daya@ymail.com (E.O.) \\ 6 Platform of Inter/Transdisciplinary Energy Research, Kyushu University, Fukuoka 819-0395, Japan; \\ farzaneh.hooman.961@m.kyushu-u.ac.jp \\ 7 Interdisciplinary Graduate School of Engineering Sciences, Kyushu University, Fukuoka 816-8580, Japan \\ * Correspondence: craviotocaballero.jordi.4e@kyoto-u.ac.jp
}

Received: 23 March 2020; Accepted: 8 May 2020; Published: 12 May 2020

\begin{abstract}
Despite the general agreement about the benefits that electrification brings to well-being, few studies have concentrated on the actual effects of electrification on the diverse non-economic dimensions of quality of life (QoL). In a multi-disciplinary and cross-institutional effort, a group of natural and social scientists have studied three electrification schemes (grid extension, centralised hybrid, and solar home systems) in four rural villages in Malaysia, Cambodia, and Myanmar. Using a novel approach with scales on several QoL measures (self-reported QoL and five QoL sub-domains; psychological, physical, social, and economic well-being; occupations; and total active time), this article presents an analysis of the effects of rural electrification on human well-being. With original data surveyed in the villages through a baseline prior to electrification and an endpoint several months after, the effects were examined through suitable statistical methods. Overall, we confirmed a positive effect of electrification in self-reported QoL levels as well as psychological, physical, and social well-being. There was, however, a certain reduction recorded in economic well-being. In the sub-domains of QoL, there were no changes after electrification in satisfaction levels concerning time use, time spent alone, housing, and personal safety, but a positive effect on satisfaction levels was observed in cooking. Finally, in terms of occupation, we observed no changes in the total hours dedicated to work and no prolonged active time on usual activities in the household. The findings provide support to the hypothesis of a positive effect on general QoL from electrification, but also suggest more precisely that, for specific QoL sub-domains, the effect might not necessarily exist, or in fact, may be negative. The article concludes by discussing differences determined by cultural aspects and technological limitations in each of the systems under study.
\end{abstract}

Keywords: QoL; rural electrification; renewables; Southeast Asia 


\section{Introduction}

In 2020, around 850 million people worldwide are still facing insufficient access to electricity, most living in rural areas of developing countries [1]. Although grid extension is considered a conventional way of improving access to electricity, it is often excessively costly. In contrast, renewable energy (RE), in particular, solar technologies, is more accessible and has opened new possibilities to supply power via off-grid systems in rural electrification projects. The implementation of RE projects has surged over the past decades under each countries' national energy plans in line with the 7th objective in the Sustainable Development Goals (SDGs): "Energy for all" [2]. As a consequence, an increasing amount of literature has been dedicated to report on the techno-economic feasibility of different rural electrification schemes [3-10], electrification policies or frameworks [11-18], as well as other social-related issues [19-24].

On a techno-economic basis, the impact of rural electrification can be associated with the scheme adopted. Grid extension is usually considered the best option as it guarantees a continuous supply with high power capability, but numerous studies have also demonstrated the feasibility of rural electrification using individual solar photovoltaic systems $[4,25]$ or centralised systems $[3,26]$. The bottom line is that the electrification scheme is one important concern to be taken into consideration for these projects.

On the other hand, despite the enormous efforts and knowledge available, the impact of electrification on human well-being and quality of life (QoL) remains vastly unexplored. In general, electrification is considered to bring positive changes to rural communities with improved health, income, education opportunities, and so on, all assumed to improve QoL. However, the existing investigations tend to concentrate on the QoL impact of rural electrification through indirect indicators, such as infant mortality, life expectancy, mean years of schooling, gross domestic product, gross national income, water access, and so on $[21,27]$. Given that the indirect approaches are generally founded on economic principles, these have several recognised limitations [28].

In contrast, less research exists using measures reflecting the everyday experiences from electrification and its subjective appraisal. Several measurements of subjective human well-being already exist and might be suitable to understand the effects of rural electrification on QoL. For example, the measurement approach provided in [29] distinguishes three domains: life satisfaction, affect, and eudemonic well-being - an Aristotelian concept related to the realisation of the person's mental potential [30]. Alternatively, another approach suggests five domains, covering material and physical well-being, relationships, personal development, fulfilment, and recreation [31]. A notable method is the Quality of Life Index [32], where perceived importance and satisfaction are given on various QoL domains. Any of the methods mentioned so far seem suitable to inform about the effects of electrification on QoL more directly.

On the other hand, the findings of studies on electrification impacts cannot be easily translated to different regions. In general, the investigations have concentrated on case studies from Africa [12,18-20,33,34] and South Asia, for example, India [35,36], Bangladesh [37], Ghana [15], Nepal [38], and Rwanda [39], to mention a few. Yet, there is a notable need for electrification in other rural contexts, where it is commonly overshadowed by other problems. Southeast Asia (SEA) is one clear example [40]. Cambodia and Myanmar are two countries having very low electrification rates in rural contexts (see Figure 1 [40]), and are well under-represented in such literature. Only a few investigations had been conducted on SEA over the years [41-45]. 


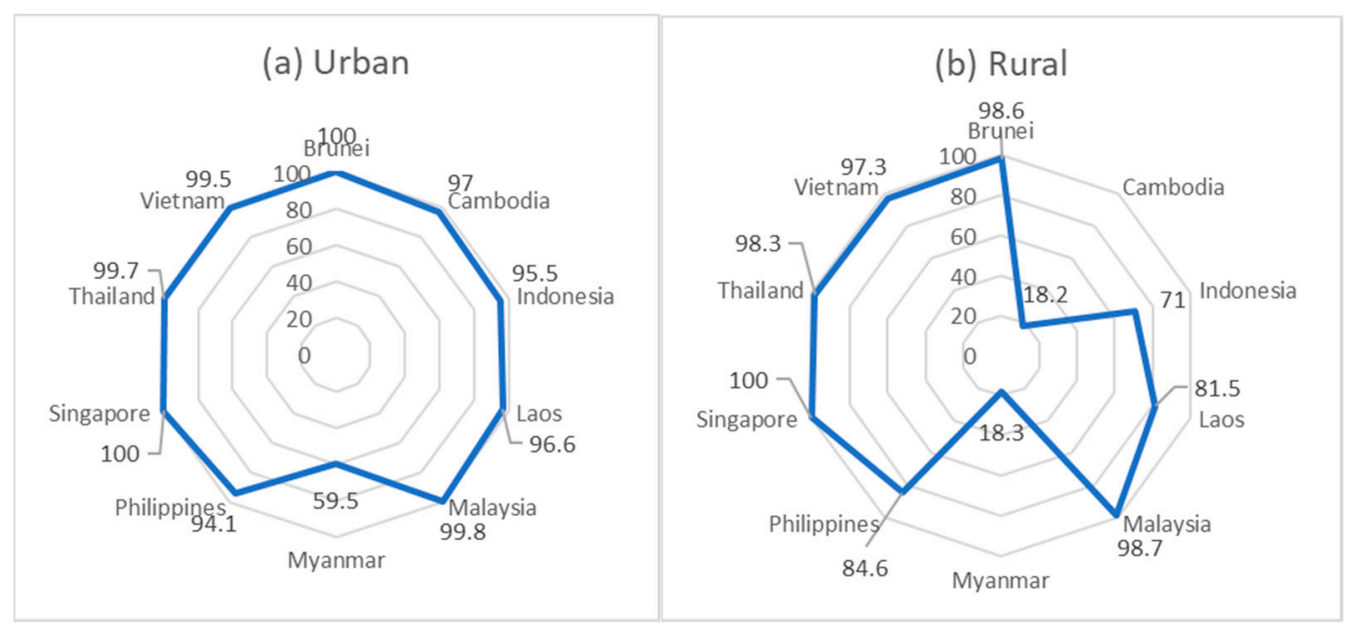

Figure 1. Percentage of electrification in urban and rural areas in Southeast Asia. Adapted from [40]. (a) Urban population electrification rates (\%) (b) Rural population electrification rates (\%).

\section{Previous Studies on Rural Electrification in Southeast Asia}

As noted previously, there are scarce analyses in SEA compared with the main body of literature, most of which concentrate on issues unrelated to QoL and rural electrification. For example, the authors of [45] state that, while the main drivers for renewable energy in developed countries consist of energy security, climate change mitigation, and economic development, in SEA, another important driver is the electrification target, particularly in rural areas. In [41], an investigation on the distributed energy system (DES) in SEA noted that some schools and clinics operate with zero or little power in these developing countries. As a result, they proposed that DES be used to serve areas where grid expansion is not economically viable, especially in Cambodia, Laos, Myanmar, and some remote islands of Indonesia. In [42], an analysis of Cambodia suggested electrification increases the household energy expenditure, but gives a positive change in terms of school enrolment. Another notable work is [44], where the lessons to be learnt from the implementation of rural electrification in Laos are examined. A comparison was made between on-grid and off-grid rural electrification schemes, where interestingly, after one year of electrification, the off-grid rural electrified communities highlighted their desire to operate refrigerators and the limitation in the solar off-grid system to support the power ratings of the refrigerator.

Overall, it can be said that literature focusing on SEA has placed little emphasis on QoL improvements, despite its growing importance in rural electrification projects. On the basis of this fact, we commissioned the present project with the main objective of investigating the effects on QoL before and after electrification in underserved communities in Myanmar, Cambodia, and Malaysia. First, different rural electrification schemes (grid extension, solar home system, centralised hybrid system) are locally implemented in four villages in the three SEA countries, which focuses this study on the cultural context of this region. The QoL measurement is comprised of several domains through field work, providing two sets of data. The first survey captures the condition prior to electrification, and then the second survey was conducted around one year after electrification so as to allow some time for the villagers to adapt to the new lifestyle. Each of these measures are taken as baselines and endpoints, and with further analysis based on statistical methods, differences between both stages were revealed.

This article is structured in five sections. Section 2 briefly presents details on the village selection. Section 3 explains the questionnaires used in the survey and the statistical methods chosen for the analysis. Section 4 proceeds with results and discussion of findings, and Section 5 summarises the conclusions of the analysis. 


\section{Villages Selection}

Four villages typical of rural Southeast Asia were selected for the study. The selection was based on the premise of no official electrification at the time of selection (in some cases, there were plans to expand the grid or to power with off-grid systems) and the willingness of the community to take part in the project. The sites are Kampung Sungai Merah and Menangkin in Malaysia, Oak Pho in Myanmar, and Thmor Keo in Cambodia. All of them have income levels below the national average, and have similar economic activities, largely based on farming and fishing. The tropical climate typical of the Southeast Asian region is also similar. Different electrification schemes, namely, grid extension, solar home system (SHS), and centralised hybrid system, have been implemented in the four villages based on the economic capacity of the project, geographical features of the location, and its proximity to grid lines. Besides, the application of different electrification schemes has provided ample opportunity for comparison among the study sites. Finally, with the exception of Oak Pho (Myanmar), the first visits to villages were carried out prior to electrification, while the second visit was done at least one year after electrification. A summary of the key data for the four rural electrification sites is given in Table 1, the geographical location of the villages is shown in Figure 2, and more details about the communities and their respective electrification schemes are provided in the following paragraphs.

Table 1. Sites and survey summary.

\begin{tabular}{|c|c|c|c|c|c|c|c|}
\hline \multirow{2}{*}{$\begin{array}{l}\text { Electricity } \\
\text { Scheme }\end{array}$} & \multirow{2}{*}{ Village } & \multirow{2}{*}{ Country } & \multirow{2}{*}{ Demographics } & \multirow{2}{*}{$\begin{array}{l}\text { Cultural } \\
\text { Profile }\end{array}$} & \multirow{2}{*}{$\begin{array}{l}\text { Electrification } \\
\text { Date }\end{array}$} & \multicolumn{2}{|c|}{ Surveys } \\
\hline & & & & & & Baseline & Endpoint \\
\hline \multirow{2}{*}{$\begin{array}{c}\text { Grid } \\
\text { Extension }\end{array}$} & Menangkin & Malaysia & $\begin{array}{l}22 \text { households } \\
(\sim 100 \text { inhab. })\end{array}$ & Iban & Jul. 2017 & $\begin{array}{c}\text { Apr. } 2016 \\
(\mathrm{n}=19)\end{array}$ & $\begin{array}{c}\text { Jul. } 2018 \\
(\mathrm{n}=12) \\
12 \text { month after }\end{array}$ \\
\hline & $\begin{array}{l}\text { Thmor } \\
\text { Keo }\end{array}$ & Cambodia & $\begin{array}{c}215 \\
\text { households }\end{array}$ & Khmer & Aug. 2017 & $\begin{array}{c}\text { Mar. } 2017 \\
(\mathrm{n}=17)\end{array}$ & $\begin{array}{c}\text { Sept. } 2018 \\
(\mathrm{n}=21) \\
13 \text { month after }\end{array}$ \\
\hline $\begin{array}{l}\text { Hybrid } \\
\text { system }\end{array}$ & Oak Pho & Myanmar & $\begin{array}{c}400 \\
\text { households } \\
(\sim 2000 \text { inhab. })\end{array}$ & Bamar & Jul. 2017 & $\begin{array}{l}\text { Nov. } 2017 \\
(\mathrm{n}=19)\end{array}$ & $\begin{array}{c}\text { Oct. } 2018 \\
(\mathrm{n}=35) \\
15 \text { month after }\end{array}$ \\
\hline $\begin{array}{l}\text { Solar } \\
\text { Home } \\
\text { System }\end{array}$ & $\begin{array}{l}\text { Kampung } \\
\text { Sungai } \\
\text { Merah }\end{array}$ & Malaysia & $\begin{array}{l}5 \text { households } \\
\text { ( 20 inhab.) }\end{array}$ & Iban & Mar. 2017 & $\begin{array}{c}\text { Dec. } 2016 \\
(\mathrm{n}=6)\end{array}$ & $\begin{array}{c}\text { Aug. } 2018 \\
(\mathrm{n}=7) \\
17 \text { month after }\end{array}$ \\
\hline
\end{tabular}

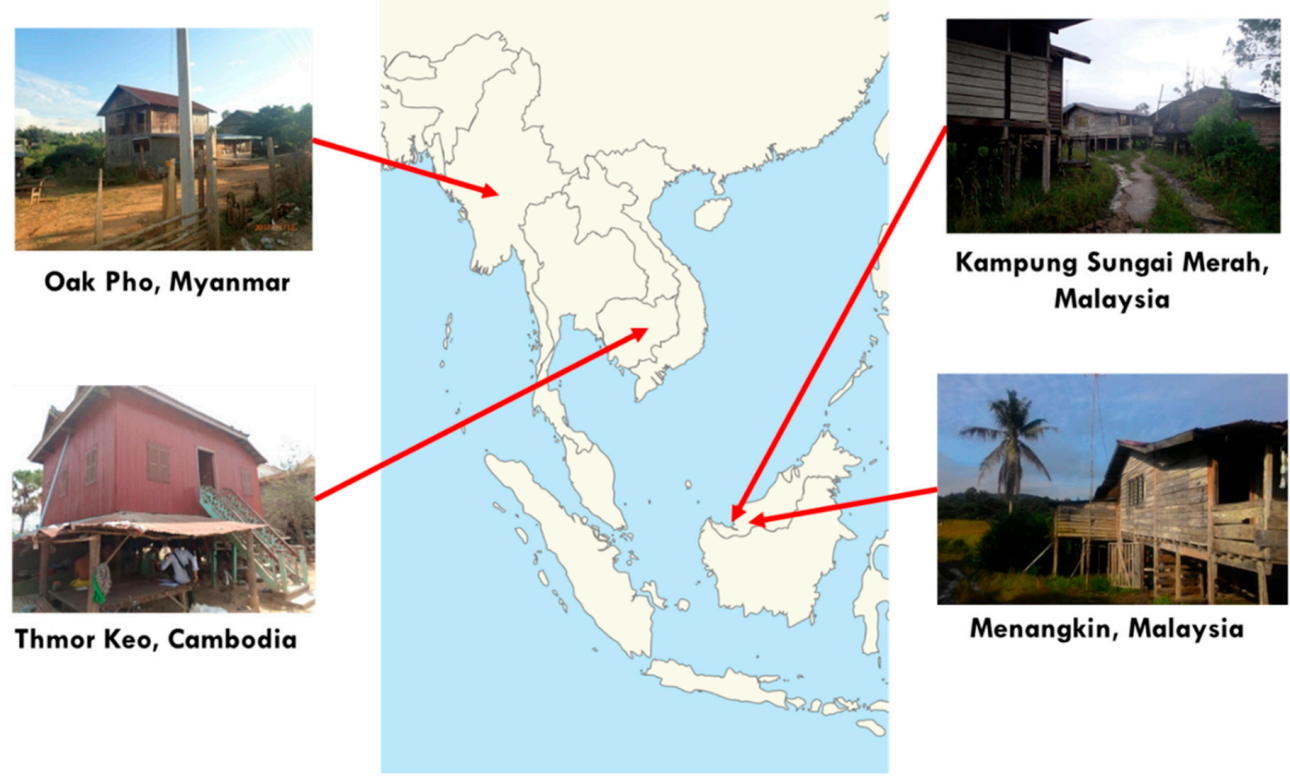

Figure 2. Electrification sites. 


\subsection{Malaysia-Kampung Sungai Merah and Menangkin}

In Malaysia, since 2015, the electricity coverage was reported to be $100 \%$ [1]. However, the coverage of electrification is not uniform. In the eastern states of Sabah and Sarawak, some of the population is living off-grid. As a matter of fact, it was reported that the rural electrification rate for Sarawak was around $89.8 \%$ in 2017 [46]. Over the past two decades, there has been a substantial effort by the government to improve electricity coverage in Sarawak, including the implementation of small-scale rural electrification projects using grid extension as well as centralised standalone systems utilizing hybrid solar-diesel or hydro-diesel configurations, as well as SHSs.

In this study, two villages with different electrification schemes, that is, grid extension and SHS, were considered. The communities in both villages belong to the Iban culture, which is the largest aboriginal group in Sarawak. Traditionally, the Iban community lives in the "Rumah Panjang", or longhouse, where different families live in rooms of a single long and narrow building and share a common veranda. While modern Iban communities such as in Menangkin and Kampung Sungai Merah no longer stay in the longhouse, they still maintain the tradition of having a strongly knitted relation, where villagers usually socialise in the house of the prominent person, generally the head of the village, during the evening time.

The first site, Kampung Sungai Merah, is a small village located on the west side of Borneo Island and a one-hour boat journey from the nearest town of Sebuyau. The village has a population of 20 inhabitants and 5 households (as of December 2018), who are mainly farmers and fishermen. The village was electrified using a 300 W SHS in February 2017 [47]. Prior to this, the villagers relied on their own diesel generators for powering lights, TV, and even one refrigerator (for one household) during the night time. The first survey was conducted in December 2016, before the installation of SHS. The follow-up survey was done in August 2018, approximately 17 months after electrification.

The second village, Menangkin, is located in the Pantu district of Sarawak, which is accessible by a $4 \mathrm{~h}$ road journey from Kuching, the biggest city in the state. Here, villagers make a living mainly from farming commercial crops, particularly pepper and oil palm. At the same time, rice is planted in low volume for self-consumption. The total number of households in the village is 22 , with approximately 100 residents. Owing to its relative proximity to the main town, the village was electrified through grid extension in mid-2017. Prior to the grid extension, the villagers relied on individual diesel generators for lighting at night. The first survey was taken in April 2016, before the electrification, while the second survey was done in July 2018, approximately one year after electrification.

\subsection{Cambodia-Thmor Keo}

In Cambodia, to meet the need of the population and society, the government has established a policy to promote and encourage the development of rural electrification; all the villages will be electrified by 2020 , and at least $70 \%$ of the households will be connected to the grid by 2030 [48]. However, a new study reveals that more than $95 \%$ of households have access to electricity if taken into consideration electricity supplied from batteries, SHS, and diesel generators [49].

Kampong Cham is a province located in the eastern part of Cambodia, which shares the borderline with Vietnam. The electricity supply services for Kampong Cham province were transferred from Rural Electricity Entrepreneur (REE) to Electricity du Cambodge (EDC) in 1998 [50]. So far, the electricity supply in this province comes from two different sources, the national grid and Vietnam [51]. Most of the villages are electrified with the national grid, yet some remote villages still rely on battery, SHS, or diesel generator for electrification.

In this paper, Thmor Keo village was selected for the investigation of QoL before and after electrification. It is an inland village located in the Batheay district of Kampong Cham province with around 215 households, mostly living from farming. Most are Buddhist with similar lifestyles. There are two types of energy consumption in their daily life, thermal energy and electrical energy. Thermal energy, which is primarily used for cooking, comes mainly from wood and liquefied petroleum gas (LPG). Prior to grid electrification, some households were running their own diesel generator, typically 
for $3-4 \mathrm{~h}$ a day during the evening and night time. A few households used SHS and rechargeable batteries for lighting, radio, and TV.

The electrification of Thmor Keo village was carried out in August 2017 by grid extension from the provincial grid. Besides the electricity bill (about $0.18 \mathrm{USD} / \mathrm{kWh}$ ), which is based on monthly electricity consumption, households are required to pay a connection fee (about 100-200 USD/house) depending on the connected capacity, when first connected to the grid. The first QoL interview was done in March 2017 (before the electrification), while the second interview was conducted in September 2018, approximately 13 months after electrification.

\subsection{Myanmar-Oak Pho}

Within SEA, electricity infrastructure in Myanmar is the least developed, where only $59.5 \%$ of the urban population is electrified as of 2017. Rural communities are even further marginalized, where only $18.3 \%$ of the population is electrified. The government has been targeting the distribution of electricity to $100 \%$ of the country by 2030 [52]. The expansion of electricity services will be supported through both grid and off-grid solutions. The Department of Rural Development (DRD) at the Ministry of Agriculture, Livestock, and Irrigation (MoALI) has been implementing the off-grid solution using SHS and hybrid mini-grid system.

In this paper, Oak Pho village in Bago province was selected for the study. There are about 400 households and approximately 2000 residents living in the village. Most of the villagers are of Bamar ethnic (major group in Myanmar), whose primary income is derived from farming and other small commercial activities such as operating shops that sell snacks and daily goods. Most of them are Buddhist. The village has a primary school and a branch of middle school, but no hospital. In July 2017, the village was electrified by a centralised hybrid system $(20 \mathrm{~kW}$ solar PVsystem with a $2 \mathrm{kAh}$ lead-acid battery and $30 \mathrm{~kW}$ diesel back-up generator), serving 120 houses in the village. In addition, electricity infrastructure for street lights and water pumping system is readily available. The Myanmar National Electrification Plan (2016-2021) has been promoting a 6/2/2 hybrid mini-grid program, which is a cost-sharing program between the government $(60 \%)$, the installer $(20 \%)$, and the community $(20 \%)$, with an initial capital of about USD 200,000. According to the system installer/operator, the diesel generator has never been turned on since its installation, owing to the low energy usage in the village. For this reason, the system can be also considered a centralised solar system. The villagers are charged through prepaid meters in each household, with a unit price of about USD 0.37 per $\mathrm{kWh}$.

As mentioned before, unlike the previous three villages, the project team was unable to arrange the first visit to the village before electrification. However, the first interview was done in November 2017, just four months after the electrification. The second interview was then conducted in October 2018, approximately 15 months after the installation.

\section{Methodology}

This section details the adopted framework, sample collection, QoL measurement, and analysis methods. The first section will describe the framework and data collection method, followed by details of structure and itemization of the questionnaire. Finally, the third section will describe the analysis methods of differentiation between the baseline and endpoint.

\subsection{Framework and Sample Collection}

The analysis was undertaken through a quantitative research design [53]. We constructed and applied the questionnaire in the form of a face-to-face interview, using the chain-referral sampling method [54]. In this way, the sample comprised responses from villagers brought in primarily by our main contact, usually the village authority. The same households were interviewed in both baseline and endpoint. As shown in Table 1, samples from Kampung Sungai Merah and Menangkin were representative of its population, given the village size. Whereas in the other locations, the use of quotas for proportionality in the sample demographics was the basis of the collected data. We acknowledge 
that, in the case of Thmor Keo and Oak Pho, our sample size could yield possible bias. In addition, we also acknowledge that, given the nature of the chain-referral method, our sample could ultimately represent respondents with similar opinions.

In extracting data, local researchers, authorities, villagers, and undergraduate and graduate students undertook the interviewing process. Local authorities and villagers spoke both the official language and the local dialect, and researchers and students usually spoke only the official one. The researchers and students helping to collect the data had training prior to the data collection in order to acquire deeper knowledge of the questionnaire and to help in possible problems when collecting data. They also helped to validate the data during the interview, and translated the content into English for the analysis. When needed, they also provided feedback on data interpretation after the analysis.

\subsection{Questionnaire Structure}

The impact on QoL was measured using a questionnaire with several categories comprising of items in nominal, ordinal satisfaction scales, and quantitative variables. The questionnaire was applied in the form of an interview. It was structured to cover QoL with its dimensions, occupation, and time of activities, as shown in Table 2. The measures are based on a well-known measure of quality of life known as the Wisconsin Quality of Life Index (WQoLI) [32].

Table 2. Questionnaire items and structure.

\begin{tabular}{|c|c|c|c|c|c|}
\hline No. & Category & Dimensions & Domains & Items & Type of Variable \\
\hline I & Demographics & - & $\begin{array}{l}\text { (1) Gender, (2) age, (3) education, } \\
\text { (4) family type, (5) occupation }\end{array}$ & 5 & Nominal \\
\hline \multirow{6}{*}{ II } & \multirow{6}{*}{ Quality of Life } & \multirow{2}{*}{$\begin{array}{l}\text { Quality of life } \\
\text { (Self-reported and } \\
\text { satisfaction } \\
\text { sub-domains) }\end{array}$} & Self-reported quality of life & 1 & $\begin{array}{l}\text { Ordinal } \\
\text { (10p scale) }\end{array}$ \\
\hline & & & $\begin{array}{c}\text { Satisfaction sub-domains: } \\
\text { (1) Time use, (2) time alone, (3) } \\
\text { housing, (4) cooking, (5) personal } \\
\text { safety }\end{array}$ & 5 & $\begin{array}{c}\text { Ordinal } \\
\text { (5p-likert scale) }\end{array}$ \\
\hline & & $\begin{array}{l}\text { Psychological } \\
\text { well-being }\end{array}$ & Self-reported mental health & 1 & $\begin{array}{c}\text { Ordinal } \\
\text { (5p-likert scale) }\end{array}$ \\
\hline & & $\begin{array}{l}\text { Physical health } \\
\text { well-being }\end{array}$ & Self-reported physical health & 1 & $\begin{array}{c}\text { Ordinal } \\
(5 p-\text {-likert scale })\end{array}$ \\
\hline & & Social well-being & $\begin{array}{l}\text { Perception on social support from } \\
\text { family and friends }\end{array}$ & 1 & $\begin{array}{c}\text { Ordinal } \\
\text { (5p-likert scale) }\end{array}$ \\
\hline & & Economic well-being & $\begin{array}{l}\text { (1) Feelings about personal wealth, } \\
\text { (2) regularity of lack of money } \\
\text { preventing activities, (3) income }\end{array}$ & 3 & $\begin{array}{c}\text { Ordinal } \\
(5 / 4 \text { p scale }) / \text { Scale }\end{array}$ \\
\hline III & Occupations & - & $\begin{array}{l}\text { Satisfaction with (1) main activity, } \\
\text { (2) hours of work }\end{array}$ & 2 & $\begin{array}{c}\text { Ordinal } \\
(5 p \text {-likert scale }) / \text { Scale } \\
\end{array}$ \\
\hline IV & Time of activities & - & Total active time & 1 & Time scale \\
\hline
\end{tabular}

The WQoLI is a measure proven in medical fields as a reliable tool for measuring multidimensional well-being among patients receiving psychological therapy. The scale was developed in North America to combine the perspectives of patient, family, and clinician in mental treatment programs [55]. It comprises objective and subjective components, which were incorporated to determine treatment goals and examine results. The original elements in the WQoLI are life satisfaction, occupational activities, psychological well-being, physical health, social relations, economics, daily living activities, symptoms, and goals [32], from which we selected items with a rational hypothetical connection with electricity. In this process, we have examined previous literature reporting on relationships between the elements and electricity use. Details on the procedure will be briefly explained below.

Quality of life and its dimensions related to electricity use

Seven of the nine elements contained in the WQoLI are related to electricity. These seven aspects were classified in four main categories (Table 2). Each category contains single or multiple dimensions, 
which comprise one or several domains in the form of question items retrieving nominal, ordinal, or scale variables. Although we have taken into account the different values implicit in every culture, we do not discard differences attributable to particular traits reflected in the judgments specific to the context under study. Given that the scale was developed in a different context to the one analysed here, cultural differences might be a vital source of interpretation, for example, stronger stress on communal activities over individual ones in specific household domains, and so on. When needed, a discussion is added correspondingly. In the following paragraphs, a detailed account of all these items and the hypothetical connection with electrification will be presented.

\subsubsection{Category 1: Demographics}

This first category in the questionnaire consists of socio-demographic information on gender, age, occupation, education, family structure, and type of housing. These are variables used in the analysis of the QoL measures.

\subsubsection{Category 2: Quality of Life}

This category comprises five dimensions related to QoL: (1) self-reported QoL and five satisfaction sub-domains, (2) psychological well-being, (3) physical health well-being, (4) social well-being, and (5) economic well-being. We will explain more details in the following subsections.

\section{A. Self-reported QoL and satisfaction sub-domains}

\section{Self-reported QoL}

Self-reported QoL is measured trough a 10-point scale question on how does the respondent feel about his well-being over the past four weeks. This measure is a direct well-being measure that has never been examined in previous literature related to the effects of rural electrification. QoL is hypothesised to increase from electrification owing to easier access to activities, medical services, and so on [42], noting also that there are some claims that electrification can bring about issues related to gender, land rights, financial problems, and polarisation [19,56,57].

Owing to the inherent nature of our measure, stemming from an individual evaluation of conditions, we hypothesise that self-reported QoL should increase after electrification owing to the influence that diverse energy services requiring electricity exert on cultural, leisure, and productive activities, as well as communication, cooking facilities and food preservation, and better sanitation.

\section{Satisfaction sub-domains}

The following five QoL sub-domains are introduced in the questionnaire. These sub-domains are all hypothesised to have a connection with rural electrification in diverse ways. Below is a description of the main hypotheses in our study.

a. Overall time use

The first QoL sub-domain is a measure reflecting satisfaction with the way time is spent. The item is taken as conceived in the WQoLI. The question item is measured in a five-point satisfaction scale, as stated below:

How satisfied or dissatisfied are you with the way you spend your time?

It can be said that, in general, electricity multiplies the number of energy services in the household and is associated with more activities [42,58,59] and extended active time [42]. 
We hypothesise that satisfaction with how respondents spend their time should increase because electricity would allow for cultural, leisure, and productive activities that could not be done before electrification, all of which have an effect on this sub-domain.

b. Time alone

The second QoL sub-domain is a measure reflecting satisfaction with time spent alone. The item is also taken directly from the WQoLI through the question measured in a five-point satisfaction scale below:

\section{How satisfied or dissatisfied are you when you are alone?}

Arguably, in some contexts, electrification might be positively associated with individual activities that might enrich the life experience of a human. Cellular phones, tablets, or computers could have a major role on individual time devoted to cultural or leisure activities. In the case of more traditional devices such as radios or TVs, the effect might not be as clear from an individual stand-point. This depends on the customs in the use of these devices and how solidly shaped is the traditional lifestyle when new technologies reach the household, because for some contexts, the technology is adopted, instead of transforming the original lifestyle.

Despite the generalised perception that satisfaction with time spent alone has positive effects on QoL owing to access to electricity, we hypothesised that, given the cultural context, this might not be easily observed because of the convivial nature of these communities in SEA.

c. Housing

The third QoL sub-domain is a measure reflecting satisfaction with housing. The item is also taken directly from the WQoLI through the question measured in a five-point satisfaction scale below:

How satisfied or dissatisfied are you with your housing?

Electrification is in general associated with better housing, increased household equipment, and greater energy services in the household [42,58-60]. We follow the hypothesis that electrification will bring about higher satisfaction with housing.

d. Cooking

The fourth QoL sub-domain is a measure reflecting satisfaction with cooking. The item is also taken directly from the WQoLI through the question measured in a five-point satisfaction scale below:

\section{How satisfied or dissatisfied are you with the food you eat?}

Cooking is one of the most fundamental energy services in households. In the Southeast Asian context, electrification can be associated with better and increased household equipment used for cooking such as rice cookers, refrigerators, mixers, and so on [58]. We state the initial hypothesis that electrification will bring about higher satisfaction with the food eaten in the household. In addition, we asked villagers about their cooking fuels.

e. Personal safety

The fifth and final QoL sub-domain is a measure reflecting satisfaction with personal safety. The item is also taken directly from the WQoLI through the question measured in a five-point satisfaction scale below:

How satisfied or dissatisfied are you with your personal safety?

Safety can take diverse standpoints, but it can be one of the most fundamental issues for households without electricity. In the case of natural disasters, electricity facilitates relief through communication 
technologies [61]. Similarly, in the case of protection against wild animals or poisonous insects [62], the use of a refrigerator can help to preserve a first aid kit at home with fundamental medicines $[63,64]$. On the other hand, the problem of theft and harm from neighbouring communities is another concern of villages without lighting $[14,65,66]$. Thus, electrification can help to prevent such concerns.

In the Southeast Asian context, electrification could be associated with any of the three matters mentioned above. Increased use of refrigerators to preserve essential medicines, radios, televisions, and other communication devices can bring about positive feelings towards safety, and the extended use of lighting can also bring about positive feelings. We thus state the hypothesis that electrification has a positive impact on personal safety.

\section{B. Psychological well-being}

For psychological well-being, the measure reveals a self-valuation of mental health. The item is also taken from the WQoLI through a question measured in a five-point scale from poor to excellent stated as follows:

\section{In the past four weeks, would you say that your mental health has been: 1 (poor)-5 (excellent)}

Although some recent studies have focused on the association between electrification and the use of appliances [61], very few have explored the possible consequences on mental health. Particularly, in electrified communities, possible distressful increments of noise levels due to the use of electric equipment for leisure cannot be ignored. In the selected villages, this could be the case, as we noticed increased noise levels after electrification during the endpoint survey. On the other hand, the opposite may be argued in the sense that appliances might contribute to a livelier environment. In any case, it is interesting to see the effects of electrification on mental health as a fundamental component of individual quality of life. In the context of the villages under study, psychological well-being is explored as a component of QoL, noting that the use of hi-fi, a local type of Karaoke machine, has increased after electrification. Given that the use of hi-fi allows for family/friend gatherings, increasing recreation time and activities, it could be associated with positive self-valuations of mental health. We thus state as a working hypothesis that electrification can possibly exert a positive impact on psychological well-being.

\section{Physical health well-being}

For physical health-related well-being, a self-valuation item of personal physical health was selected. The question is also taken from the WQoLI in a five-point scale measurement stated as follows:

\section{In the past four weeks, would you say that your physical health has been: 1 (poor)-5 (excellent)}

Similarly to psychological well-being, there is scarce literature on the use of appliances with possible positive (or negative) consequences on physical health. The most straightforward connection could be the use of refrigerators, which can drastically change the household capabilities to preserve medicines to stabilise fever and other afflictions suffered from injuries or contact with wild animals $[58,63,64]$. This potential use of electricity to increase the self-reported health levels currently contrasts with the reality within these communities, where herbs and traditional medicines are the preferred way of curing illness or injuries. On the other hand, there might be more indirect effects such as increased communications with other villagers and communities nearby from the prolonged availability of smartphones, cellular phones, and other communication devices, as well as increased access to information regarding medical treatment. In the context of our villages, physical well-being is hypothesised to receive a positive effect from electrification owing to all these concerns. 


\section{Social well-being}

Needless to say, electricity in connection with socialisation in the household is one significant gap in the related literature. We adopted as our measuring item a self-valuation of how much support is received from others. The question, also taken from the WQoLI, comprises a three-point ordinal measurement stated as follows:

During the past four weeks, you have:

1. had infrequent support from family and friends or only when absolutely necessary (Poor)

2. been receiving only moderate support from family and friends (Moderate)

3. been having good relationships with others and receiving support from family and friends (Good)

This QoL dimension is probably the one with the strongest connection to local values and customs, thus being highly contextual. However, the bedrock of this social interaction might be on the level of support that people receive from others, despite contextual differences $[67,68]$. This rationale lines up with the medical essence of the original QoL measurement, which intended to inform therapists about how the individual is experiencing isolation [55]. Considering this, the question is aimed to estimate how much of such feelings are prevalent among individuals once electricity starts changing the social interaction they have with friends and other family members as daily activities evolve.

\section{E. Economic well-being}

The final well-being dimension relates to economic conditions and perceptions of the respondents. The measurement is done with items capturing self-judgments on household economy, income change, and expenditures related to electricity. Three questions are examined as stated below:

a. Perception about personal wealth

The first question is a self-judgment about the total amount of money owned in a five-point ordinal measurement. It is stated as follows:

How do you feel about the amount of money you have? 1 (poor)-5 (excellent)

b. Perception about income change

The second question is a four-point ordinal measurement on the perception of income after electrification. It is stated as follows:

Does your income increase after electrification?

1. No decrease

2. No, the same as before

3. Somewhat yes

4. Definitely yes

c. Expenses on electricity

The third question is a scale measurement of the actual monthly expenditure level on electricity in the household. It is retrieved through the following question:

How much money do you need for electricity (currency/month)?

With the use of actual income levels, we calculated the share of expenditure on electricity per month and used it for comparisons.

Electrification is generally thought to bring about increases in household income due to extended productive activities [23,69-71]. In some cases, however, there has been evidence that 
only when productive activities take place within the household, electricity impacts the most [72]. More subjective judgements on the household economy are virtually unexplored, including own judgments about economic conditions or the effect electricity payments impose on the household budget. The consideration of objective and subjective measures on the economic impact of electricity takes into account the actual effect on income levels in conjunction with the perception of this effect, which is strongly associated with overall QoL.

\subsubsection{Category 3: Occupation}

Besides the previous categories on QoL measures, the third category on occupation and work complements this analysis.

This section comprises two question items pertaining to the main occupation of the respondent. The first one is a scale measure of working hours. The second is a more personal judgement about the occupation through a five-point satisfaction measure on that main activity. Both measures are asked with the following question items:

a. Hours of work

About how many hours a week do you work or go to school?

b. Satisfaction with main activity

How satisfied or dissatisfied are you with the main activity that you do?

In the related literature, electrification is thought to bring about increases in productive activities and, consequently, hours of work $[63,64,72,73]$. However, no information is available on the effects electrification has on occupational satisfaction. This is the reason to consider both the objective and subjective measures on the relationship between electricity and main occupation.

\subsubsection{Category 4: Active Time}

Lastly, category 4 provides a measure of active time. This category also complements the QoL analysis providing insight on interpreting the results. Two scale measures, wake up time and sleep time, comprise the question items, and their subtraction yields the working variable: total active time. In the related literature, it is usual to find support for the premise that electrification expands active time as hours spent working $[63,64,72,73]$. However, it is debatable as to what extent these claims hold in the particular contexts of SEA, where culture might play a decisive role in household activities. On this basis, total active time is examined in conjunction with occupations and the QoL dimensions.

\subsection{Analysis Methods}

Using box plots, we graphically summarise the centre and variability of the data collected in the baseline and endpoints, and draw initial conclusions about the effects of electrification. Potential outliers are included in the figures following the SPSS labelling criteria: Extreme outliers are values above the $3 \times$ IQR criteria identified with an asterix, while "Far out" outliers are values above the $1.5 \times \mathrm{IQR}$ (Interquartile range) criteria and below the $3 \times \mathrm{IQR}$ criteria identified with a small circle. We complement the graphical representation with results of median tests and analysis of variance (ANOVA) tests in brackets inside the manuscript to verify if the differences were statistically significant.

\section{Results}

\subsection{Category 1: Demographics}

Key demographics are summarised in Figures 3-7. From here, it was observed that the sample was balanced between genders, and that respondents below 25 years old were underrepresented, but the 
four remaining age cohorts above were relatively balanced in number. In addition, most respondents completed primary education, were married and lived together with their family (type of household), and declared farming as their main occupation (Figure 8). The dominant type of households in the sample (Figure 7) were composed of a variety, ranging from nuclear families (parents and children) to extended families (those living together with grandparents and/or relatives). The proportion of families within all types of households are similar in the three countries.

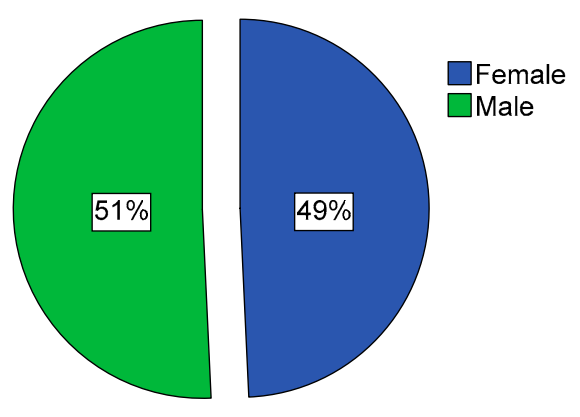

Figure 3. Gender.

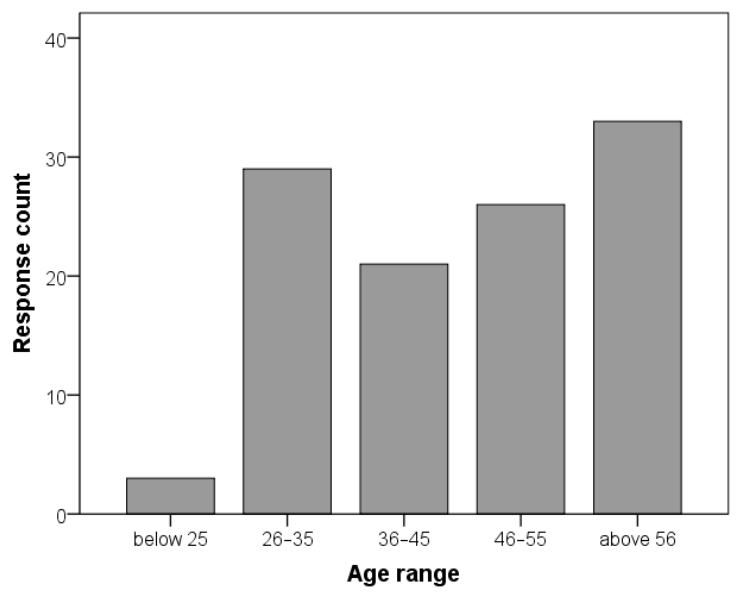

Figure 4. Age range.

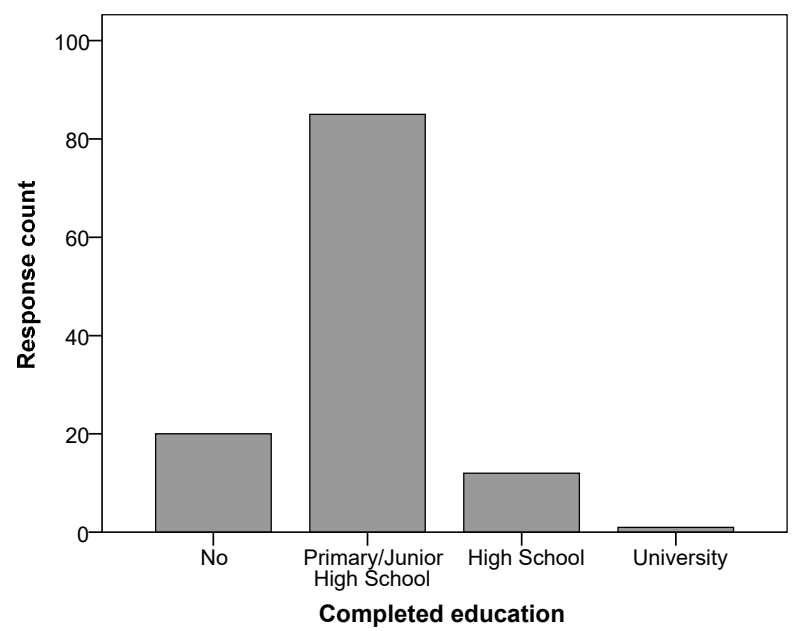

Figure 5. Education level. 


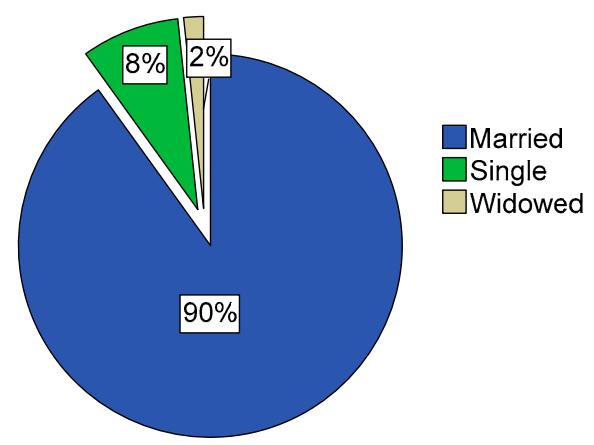

Figure 6. Marital Status.

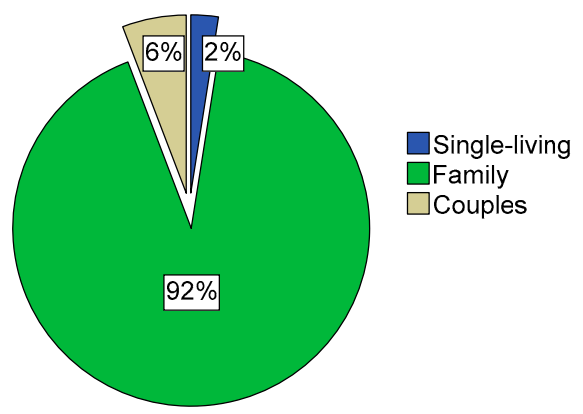

Figure 7. Type of household.

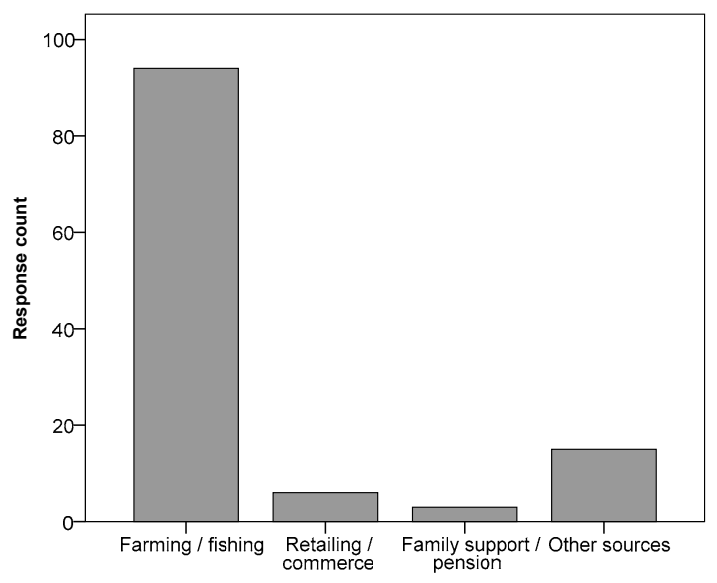

Figure 8. Source of income.

It is important to note that each of the categories here presented have the potential to be analysed more exhaustively in terms of the QoL measures studied, but this would go beyond the scope of this article. For example, gender as a social construct requires a deeper investigation into the social and cultural implications given in rural electrification effects. The same would apply for other variables such as age and education groups, as well as types of families. We have incorporated some of these aspects as far as possible in our interpretation of the results and discussion.

\subsection{Category 2: Quality of Life}

\subsubsection{Self-reported QoL and Satisfaction Sub-Domains}

Overall, there was an increase in the levels of self-reported QoL. Figure 9 shows how the median score in the 10-point scale item rose after electrification in all types of systems. Given that QoL distributions were found to be left-skewed, a median test confirmed that the increase observed in the hybrid system, the greatest among the systems, was significant $\left(X^{2}=13.1, p<0.05\right)$. Nevertheless, 
the QoL median levels for the grid and SHS systems clearly demonstrate an increase, providing further support to the overall hypothesis that higher QoL levels were brought about by electrification. One of the main drivers for the advancement in QoL is the power and energy capacities offered to the different rural communities. Concerning this, the grid should offer the highest QoL advancement owing to its ability to deliver the highest power and energy capacities, and thus offering the highest flexibility in the choice of appliances and simultaneous operation of appliances, followed by the hybrid system and the SHS. However, the results showed that the hybrid system recorded the highest self-reported QoL advancement, surpassing the grid and SHS. We conclude that the significant increase in self-reported QoL in the hybrid system in Oak Pho, Myanmar can be attibuted to the severe state of deprivation of electricity before being formally electrified in comparison with Kampung Sungai Merah and Menangkin running on SHS and grid, where villagers in the two sites were already running diesel generators prior to electrification. With these results, it can be said that electrification had positive effects on human well-being, as seen through the use of this more direct measure.

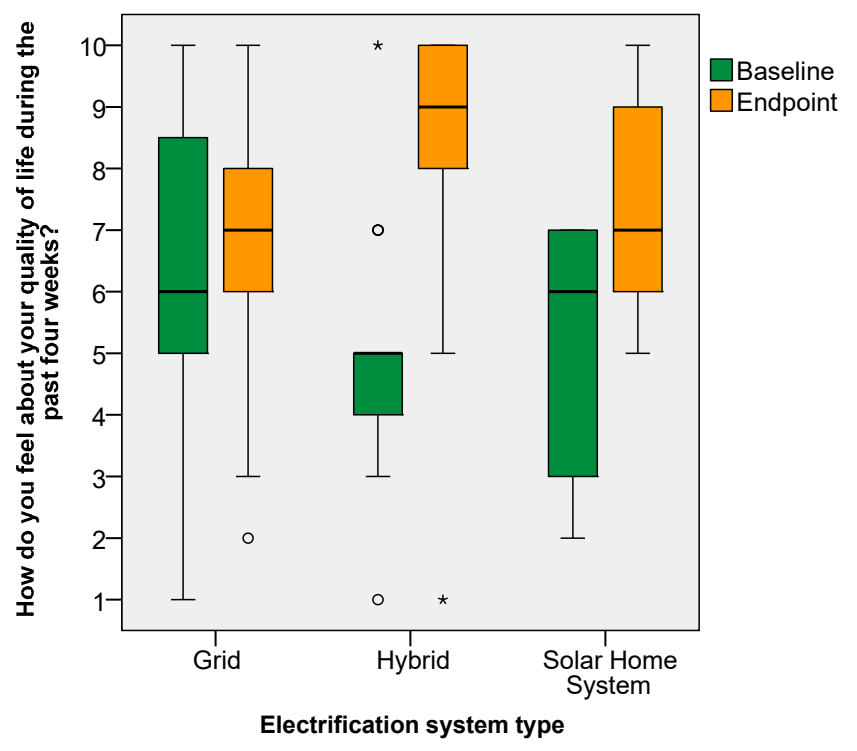

Figure 9. Boxplots of self-reported quality of life (QoL); scale from 1 (lowest) to 10 (highest).

Among the dimensions hypothesised as having effects from electrification, we found a moderate increase in the cooking-related sub-domain and no effect on the other four sub-domains. These outcomes are explained and discussed in detailed below.

a. Overall time use and time alone

Median levels of satisfaction with how time is used and time spent alone remained similar after electrification. Unexpectedly, electricity did not seem to reflect in extended time using electronic devices typically associated with solitary activities such as the use of cellular phones or tablets. In the cultural context of the villages, time spent alone has predominantly less importance than time spent with family, thus local culture might explain the outcomes. In other words, electrification does not affect villagers' use of their time because people's habits have not been changed toward such practices, at least in the one-year span of the study. On the other hand, there were weak correlations between self-reported QoL and both measures $\left(r_{s}=0.36, p<0.05\right.$ for overall time use and $r_{s}=0.069, p=0.438$ for time alone), confirming that satisfaction with the way people spend time and time spent alone could not entirely be correlated with QoL. On the whole, these results suggest that there is no clear effect from electrification in this sub-domain, yet a longer-span view is worth analysing. There is evidence that longer periods unveil changes in the behaviour patterns and particularly gender relations concerning time use [74]. Differences might be brought about after the slow-paced change of lifestyle and the value 
given to time alone with the use of electronic devices, as noted in other contexts [58], both interesting aspects to explore in further research.

\section{b. Housing}

Another unexpected outcome was that electrification did not have an effect on the satisfaction levels with housing. Although electrification could affect the villagers' perception about their home, we did not find any change between baseline and endpoint for this QoL sub-domain. We noticed that the use of air conditioning was virtually inexistent owing to their unaffordability and insufficient power ratings required to run them, and foremost because the houses are not designed to accommodate the equipment. The open nature of the rooms explains the more extensive use of fans to cool down space. Arguably, the question item could be interpreted with a closer relationship with the construction of the house and not the energy services provided inside, but these outcomes initially suggest that electrification has no clear effect on the satisfaction with housing at least in the short-term perspective.

\section{c. Cooking}

In the case of the cooking-related QoL sub-domain, electrification had a moderate effect on the satisfaction levels with the food consumed. Figure 10 reveals a positive increase in satisfaction levels after electrification (grid: $\mathrm{X}^{2}=0.251, p=0.61$; hybrid: $\mathrm{X}^{2}=0.884, p=0.347$; SHS: $\mathrm{X}^{2}=1$ ). Overall, we can argue in favour of electricity having a positive effect on this sub-domain, and that the use of rice cookers and refrigerators might explain the outcomes. The number of appliances retrieved through the questionnaire came in hand here. On the one hand, the power capacity on households electrified through grid extension undoubtedly allowed for the use of rice cookers and other higher power appliances. For the SHS, in contrast, such capacity was not available, and this might be reflected through a more moderate increase in appliance use and the distribution of satisfaction scores. The hybrid system, on the other hand, can supply power for appliances, but their use is rather limited, because the price per kWh for such a system is much higher than for others (roughly $0.37 \mathrm{USD} / \mathrm{kWh}$ in Oak Pho). This economically restrained condition might be reflected in a small rise of the median level without any change in the distributions (see hybrid in Figure 10).

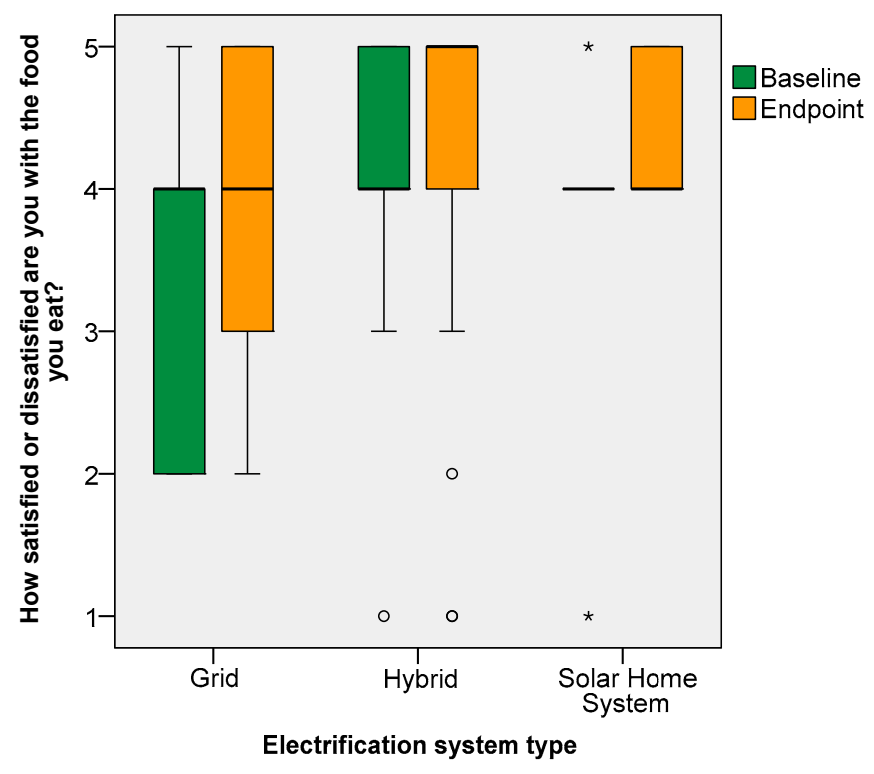

Figure 10. Boxplots of cooking; scale from 1 (very dissatisfied) to 5 (very satisfied).

It is important to note that the purchase of essential appliances such as refrigerators, cooking stoves, ovens, kettles, or even productivity-related equipment observed to improve the QoL sub-domain does not necessarily reflect inherent power relations between genders observed previously in cooking-related 
activities [75]. This is important given that more comprehensive cooking-related QoL measures would necessarily comprise wider aspects.

In sum, electrification seems to have some positive effect on the cooking-related QoL sub-domain, albeit moderate.

d. Personal safety

Finally, there was support for the hypothesis that electrification has a positive impact on personal safety. However, this outcome seems to depend on how isolated the village is from others. Electrification seems to gain importance in the sense of safety in less isolated villages. This was confirmed by comparing the remote SHS village (Kampung Sungai Merah) and one of the villages connected to the grid (Thmor Keo). Figure 11 demonstrates that, after electrification, there was no change on the median satisfaction with safety for the SHS, whereas for the one connected to the grid, which had several neighbouring settlements nearby, there was a one-point increase in the median levels (grid: $X^{2}=0.453, p=0.5$; SHS: $X^{2}=0.061$ ). It can thus be argued that electrification provides a higher sense of personal safety only when multiple villages are close together. However, the outcomes should be taken with care as differences were not significant from the median tests, and it is unclear if answers are related to personal safety from weaker community ties or other concerns, such as threats from wild animals. In sum, electrification might have a positive impact on personal safety depending on location and importance given to safety among villagers.

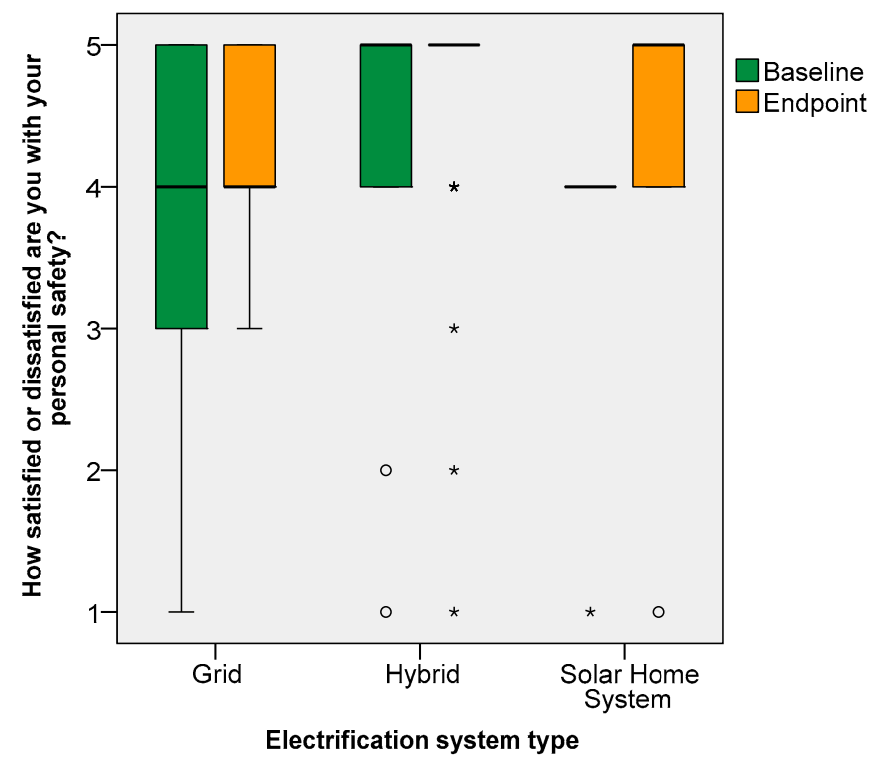

Figure 11. Boxplots of personal safety; scale from 1 (very dissatisfied) to 5 (very satisfied).

\subsubsection{Psychological Well-Being}

For psychological well-being, electrification is associated with a positive effect on self-reported mental health. In all system cases, there was a positive increase observed in the distributions and median levels of this part of QoL (see Figure 12). One possible reason is that communication devices provide information that has an impact on mental health. Information regarding weather reports for fisherman and farmers, essential for their occupations; information for women to become aware about their rights; information for men to learn domestic violence is not acceptable; healthcare information; and other information increasing the feelings of belonging to a country, region, or particular group. 


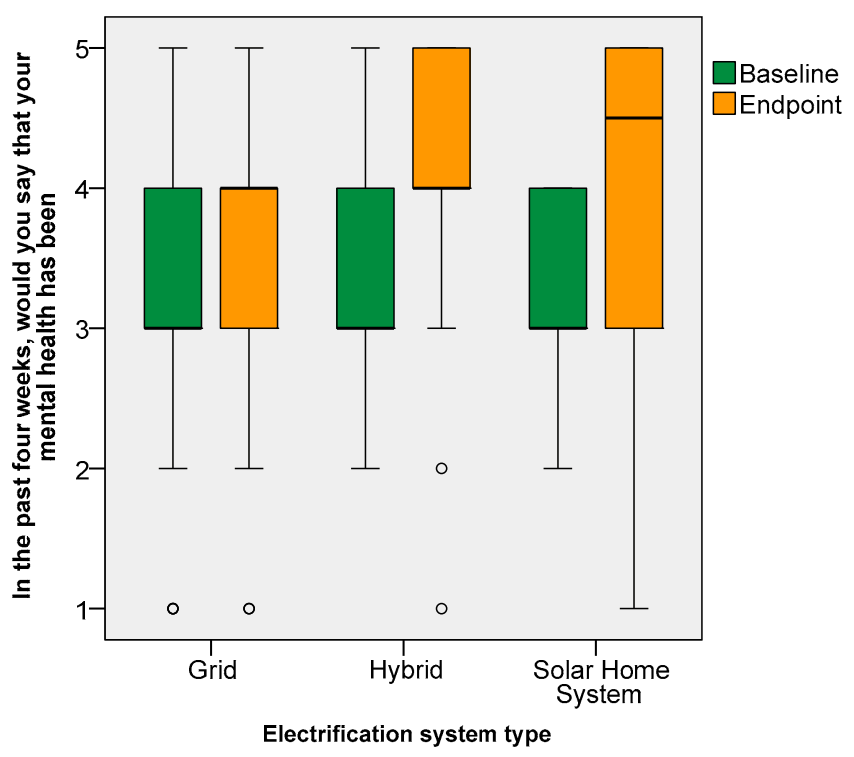

Figure 12. Boxplots of psychological well-being; scale from 1 (poor) to 5 (excellent).

Another possible reason for these outcomes is that electrification has contributed to a more lively community environment. This was suggested by the testimony of survey takers, who perceived that sounds emitted by radios and other entertainment devices switched on during day time had increased after electrification. This is not conclusive, but rather an alternative hypothesis explaining the positive effect on self-reported psychological well-being among villagers.

\subsubsection{Physical Health-Related Well-Being}

In general, there was an increase in the self-reported health outcomes, especially for the hybrid and SHS systems. Figure 13 shows this noticeable rise on the median levels (grid: $X^{2}=0.364, p=0.546$; hybrid: $X^{2}=2.49, p=0.115$; SHS: $X^{2}=0.192$ ). Although there was no use of electricity to preserve medicines or to provide service in clinics, which could objectively explain the outcomes, there seems to be an improvement in personal perception of health without any apparent direct effect. This might be explained by an increase in secure feelings owing to the improved availability of communication for villagers. In any case, an increase in the self-reported health outcomes observed is not easily explained in terms of electrification. We need a longer span of observation of the villagers' physical health after electrification.

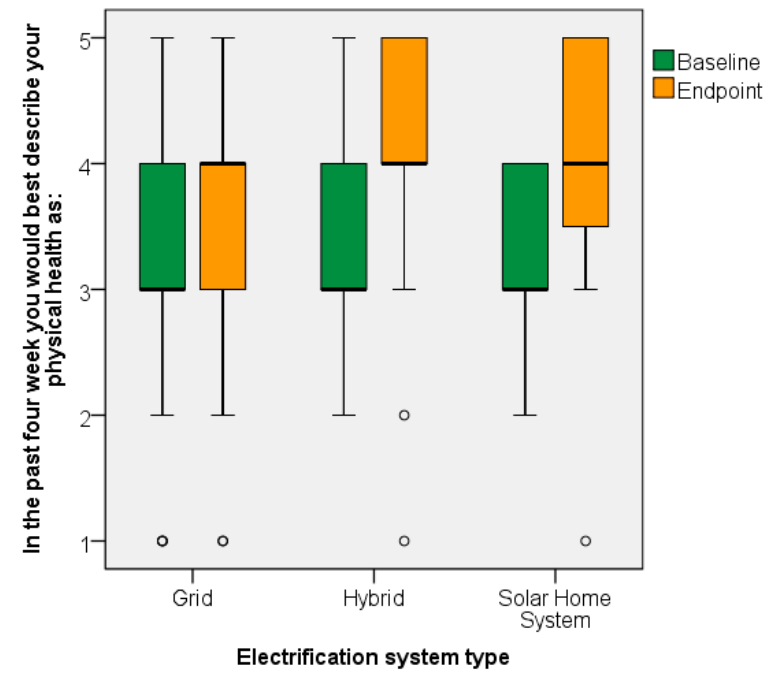

Figure 13. Boxplots of physical health-related well-being; scale from 1 (poor) to 5 (excellent). 


\subsubsection{Social Well-Being}

In terms of social well-being, there is no noticeable difference between baseline and endpoint (Figure 14). This probably has more to do with culture than any other previously analysed measure, because socialisation is closely related to the local values, customs, and habits. Parallel to what has been discussed for the time sub-domain, electrification seems to exert little, if no influence on satisfaction with the social life of the villagers, because in the cultural context of these Southeast Asian communities, socialisation is predominantly maintained within the family, and electrification might not exert any influence on these already strongly entrenched habits under the analysed time span. In longer spans, outcomes could change as well as daily activities, which in turn would lead to scrutinise more complex lifestyles, where socialization would take place in more diverse settings.

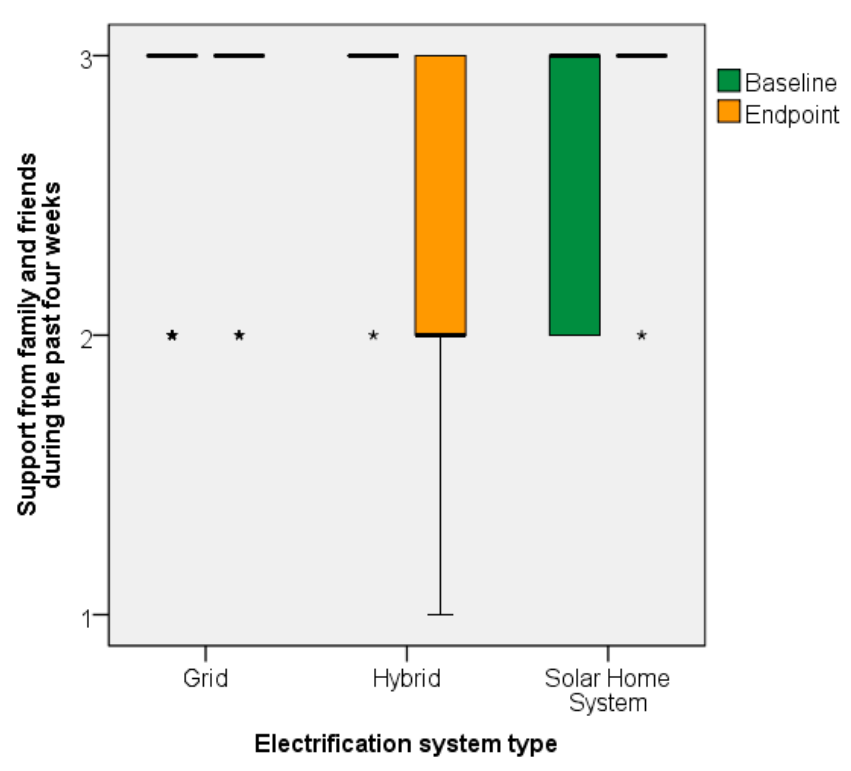

Figure 14. Boxplots of social well-being: scale in 1 (poor), 2 (moderate), and 3 (good).

Outward migration could be one concern affecting the observed outcomes, but this is not entirely clear. In the most remote of the villages where the SHSs were installed (Sarawak, Malaysia), migration is a serious concern, but for the hybrid system (Oak Pho, Mynamar), the population would normally not migrate outside. For the grid extension (Thmor Keo, Cambodia), the proximity to the city allowed people to commute for work in the neighbouring town, resulting in less migration.

\subsubsection{Economic Well-Being}

Finally, for the economic well-being, the outcomes show that electrification did not seem to represent a considerable increase in income or economic burden on the household budget, although changes were observed in the perception about expenses, income, and personal wealth.

In the first place, the estimated expenditure on electricity as a share of household income ranged from 1 to 7 percent at the endpoint (Table 3), in the sequence Oak Pho, Menangkin, Kampung Sungai Merah, and Thmor Keo. Thmor Keo and Oak Pho recorded an increasing trend in the percentage of income allocated to electricity, while both the SHS and grid electrification systems in Malaysia recorded a decrease. Compared with Malaysia, where diesel generators were used and represented a considerable share of household expenditure, there was no means of generating electricity prior to formal electrification in Cambodia and Myanmar. This explains the decrease observed in Malaysia. 
Table 3. Economic well-being indicators.

\begin{tabular}{ccccccc}
\hline Scheme & Village & Country & $\begin{array}{c}\text { Electricity } \\
\text { Expenses }\end{array}$ & $\begin{array}{c}\text { AIncome\% after } \\
\text { Electrification }\end{array}$ & $\begin{array}{c}\text { Income Change } \\
\text { (Perception) }\end{array}$ & $\begin{array}{c}\text { Satisfaction with } \\
\text { Money Owned }\end{array}$ \\
\hline $\begin{array}{c}\text { Grid } \\
\text { Extension }\end{array}$ & Menangkin & Malaysia & $\downarrow$ & From 30\% to 3-7\% & $\downarrow$ & No change \\
\cline { 2 - 7 } & Thmor Keo & Cambodia & $\uparrow$ & From 1\% to 5-6\% & $\uparrow$ & $\uparrow$ \\
\hline $\begin{array}{c}\text { Hybrid } \\
\text { system }\end{array}$ & Oak Pho & Myanmar & $\uparrow$ & From 0\% to 1\% & No change & No change \\
\hline $\begin{array}{c}\text { Solar Home } \\
\text { System }\end{array}$ & $\begin{array}{c}\text { Kampung } \\
\text { Sungai } \\
\text { Merah }\end{array}$ & Malaysia & $\downarrow$ & From 20\% to 4\% & $\uparrow$ & $\uparrow$ \\
\hline
\end{tabular}

Income also showed differences among villages. In the grid-connected village in Cambodia and the one with the SHS in Malaysia, income was perceived to have risen. There was no change in the one with the hybrid system in Myanmar, and a reduction in the grid extension in Malaysia. On the basis of the testimony of the villagers in grid extension in Malaysia, it was reported that the fluctuation in prices of agricultural products had a considerable effect on this perception.

Finally, satisfaction with personal wealth observed a consistent pattern with income and expenditure. A positive change was observed for the SHS in Malaysia and for grid extension in Cambodia, but no change for grid extension in Malaysia and the hybrid system in Myanmar.

All these results together suggest that electrification imposes a certain economic burden on the household budget only when there is absolute deprivation of electric power. However, this share is minimal and probably not consequential in the overall satisfaction with personal wealth. In contrast, electrification does seem to substantially reduce the household expenses of those using diesel generators prior to electrification, which reported one case of a positive change on the satisfaction levels with the amount of money owned.

\subsection{Category 3: Occupations}

Overall, after electrification, the number of hours dedicated to work reduced regardless of gender and occupation. Reduction in working hours was in the range of 5 for the SHS, scaling to 10 for grid extension, and almost 15 for the hybrid system (see Figure 15). In the previous analysis of QoL dimensions, electrification was primarily observed in connection with activities within the household, which might explain the decrease of hours working outside the house. As most of the respondents were dedicated to farming and fishing, we hypothesise that electrification does not have a direct effect on extended business hours, and rather on the time villagers decide to spend inside the house at the expense of working outside. For other cases where the household income is obtained from other indoor activities, for example, retailing or handcrafting, the hypothesis might be different. However, there are no sufficient data to support or oppose this premise. In general, we have found that the total hours dedicated to work decreased after electrification. This is in line with other previous findings suggesting that working patterns in rural communities change little with the advent of electricity when activities are mainly governed by the sun [76].

In terms of satisfaction with the primary activities, there was little or no increase in the median levels, but this result differed by segments. First, it was observed that, for males, the median levels increased in two of the three systems, and for females, the levels remained and even slightly decreased. This most likely suggests that electrification has direct implications on the primary activities by gender and, for females, the effect is more negative than for males. Looking at employment categories, for the most part, median levels slightly increased with the exception of houseworkers and grid-connected farmers, who reported a slight reduction after electrification (see Figure 16). 


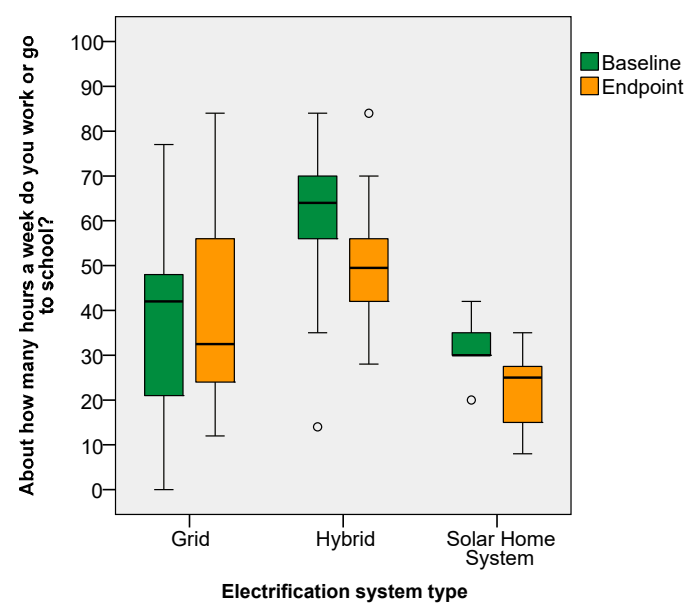

Figure 15. Boxplots of number of hours dedicated to work.

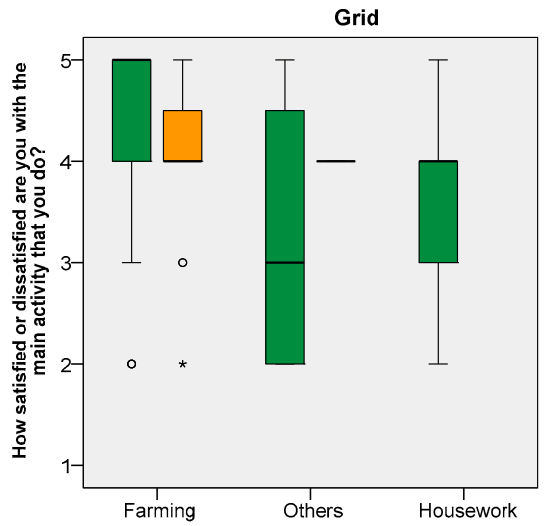

(a)

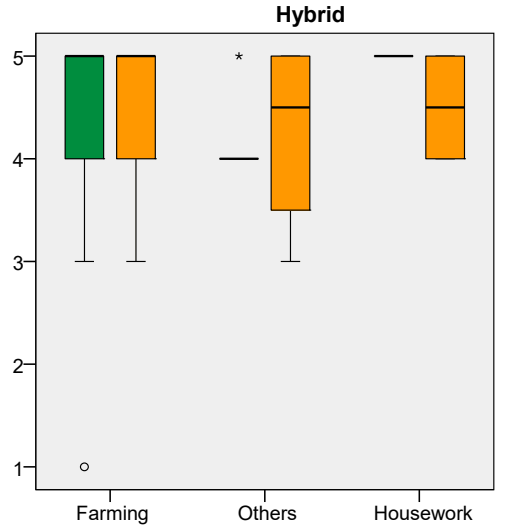

(b)

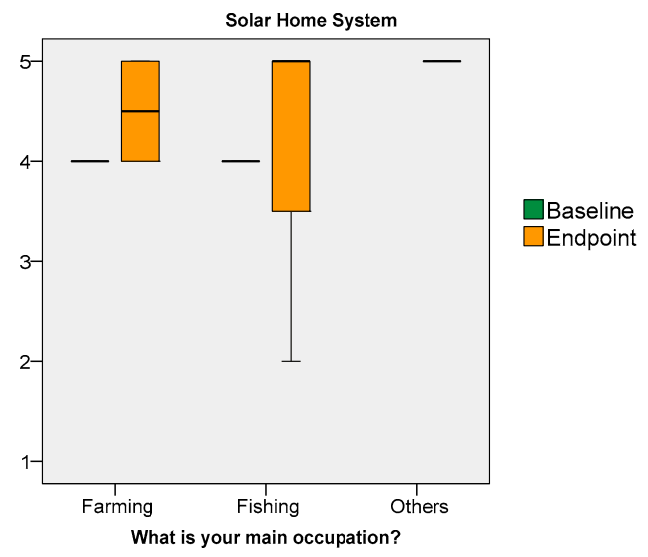

(c)

Figure 16. Boxplots of satisfaction with main activity; scale from 1 (very dissatisfied) to 5 (very satisfied). (a) Grid (b) Hybrid (c) Solar Home System.

Overall, the results point to conclude that, at least in the short-term perspective, electrification or a more secure supply of electricity in the house might be perceived as a novelty that comes with a trade-off in terms of the work activities outside the home. However, this effect on work is not necessarily negative or positive with respect to how satisfied people are with their primary activities. 


\subsection{Category 4: Active Time}

Lastly, we confirmed differences in the total active time between baseline and endpoint, but these were found to be rather small and not significant. Villagers with the hybrid systems decreased the median number of hours from wake up to sleep time as well as villagers with the SHS. In contrast, the median levels remained the same among villagers with grid extension (Figure 17). In terms of mean values, these outcomes translated into a reduction of roughly $57 \mathrm{~min}$ for the hybrid system and $16 \mathrm{~min}$ for the SHS, and an increase of $22 \mathrm{~min}$ for grid extension. These differences, although apparent, did not provide sufficient evidence to corroborate a significant change (ANOVA for grid: $\mathrm{F}(1,65)=1.345$, $p=0.250$; hybrid: $\mathrm{F}(1,47)=10.561, p=0.002$; SHS: $\mathrm{F}(1,11)=0.179, p=0.68)$. Despite having noticed that the newly installed lights in some cases kept the villagers staying up later than usual, over time, this behaviour might have diminished as the hype from electrification at the early stage finished. In addition, the results in the section of demographics demonstrate that the main occupation of the villagers was farming, thus adding to the argument that electrification has no effect on the total active time, mainly because working time is governed by day light. In general, active time remained the same in the one year of analysis.

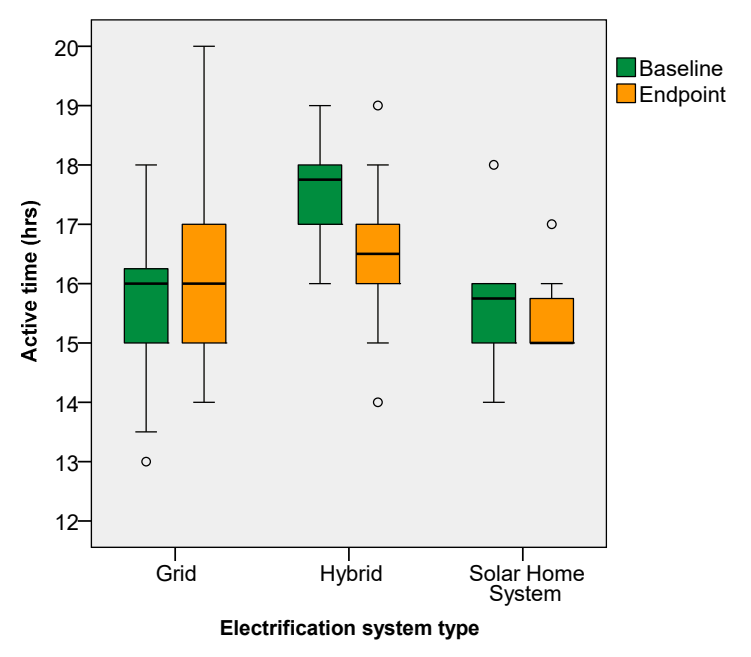

Figure 17. Boxplots of active time.

\section{Discussion}

Apart from the preceding sections, there are some other notable qualitative observations from the villages that are highlighted in this section. It is noted that electrification in the four villages did not translate directly into a substantial increase in income or working time, as suggested in some literature [23,69-71]. This is mainly because of two reasons: Firstly, the villagers, who were mostly farmers and fishermen, could not directly increase their working time or productivity through the use of electricity. Instead, they improved their comfort level through more extensive use of electric power for light bulbs and fans. In other words, electrification translated into the possibility to spend income on housing, as observed in the official household survey in Cambodia [77]. This evoked the energy services ladder hypothesis, where subsistence needs among low-incomes shift to "comfort and cleanliness" as income increases [78-80]. Our analysis may attest to how electrification is associated with such a shift in needs, directing preferences for household equipment associated with energy services connected with "new" needs. In the same vein, the income of the villagers was heavily influenced by commodity prices, which fluctuate with market demand, thus supporting our argument.

Second, the installed power and energy capacity also played a role. The communities, besides those enjoying electricity from grid extension, generally receive the power that is only sufficient for the most basic life necessities such as lightings, basic cooling in tropical climate, and moderate levels of modern necessities such as cell phones and radio, especially in the case of SHS. While powering 
televisions may be possible, it is not guaranteed. Beyond that, appliances such as refrigerators, cooking stoves, ovens, kettles, or even productivity-related equipment, which may further improve their QoL, are way above the ratings of the installed power capacity.

Furthermore, a period of time is generally required for the villagers to adapt and discover the potential of electricity to improve their QoL further. Time is also required for the community to procure new appliances, as affordability is one of the frequently cited hardships felt by the villagers. It is expected that only through a longer period of time, the community can gather enough savings for new appliances such as televisions or productivity-related appliances. This is aligned with the findings in [58], where the uptake rate of television had been found to be gradual over several years in a village in India. In addition, QoL indicators such as improvements in health would not change within months or a year after electrification. Clearly, there is room for a longer-span study.

Taking the scenario in Kampung Sungai Merah, Malaysia as an example, where fishing is the main income-generating activity. Only after multiple years post-electrification, the villagers started toying with the idea of preserving perishable harvest and food in the warm tropical climate. They procured a refrigerator, hoping to market their unsold catch the next day. Though the outcome was less successful owing to the limited power capacity from the SHS, they eventually switched to the more expensive diesel generator for electricity. Nevertheless, the above example demonstrates the roles of the power capacity and time factors mentioned previously.

Besides that, the actual utilization of electricity could greatly depend on the level of deprivation of the villagers prior to electrification. For instance, some villagers in Malaysia (Kampung Sungai Merah and Menangkin) were running generators for 3-4 $\mathrm{h}$ daily prior to the electrification, compared with villagers from Cambodia, who generally had no access at all to electricity. The uses given to electricity at the endpoint could differ given the previous experience, which is ultimately affected by the initial level of deprivation.

Additionally, other aspects related to geography, demographics, and culture may also impact the outcomes. As pointed out in our first analysis of electrification in Malaysia [47] and briefly mentioned in Section 2, Iban communities are close-knitted societies with traditions of socialising in one specific communal area of the households, that is, the "rumah panjang", reducing the use of electricity in private space for diverse energy services, for example, room temperature regulation and entertainment. While both communities in Menangkin and Kampung Sungai Merah still maintain such culture, electrification could reduce the communal activities as each individual household starts to have their own entertainment (TV) and other electrical appliances. This is still debatable, as there is evidence in other contexts that cultural behaviour does change over time [81]. On the other hand, climate needs can also affect certain appliance use, and cultural preferences such as ingredients in the regular diet do not reflect higher electricity needs for food preservation. In terms of cooking fuel, however, according to our observation, it is very clear that Iban members prefer the taste of food prepared with firewood.

Another aspect that should be considered in the interpretation of the outcomes is the gender power relations. Generally, it has been acknowledged that men tend to decide about household purchases, even in contexts where women earn income $[19,74,82]$. This affects both genders in several of the QoL domains studied here. For example, in the domain of cooking, where decisions on appliance purchases take a fundamental role, gender may affect the incorporation of electricity into cooking activities. Consequently, the way household members spend time could also be affected, explaining differences by gender inside households. In some contexts, women-owned households are more likely to lack access to electricity [83], further demonstrating the importance of gender relations. Future studies should point in this direction.

In addition, many other factors may affect the outcomes presented here. For example, political structures, social learning, technological advancement, urban/rural conflicts, and competition, as well as more concrete aspects such as spatial proximity to cities and cost of capacity expansion. All of these are important concerns in understanding the dynamics of QoL change with electrification, and future scenarios of electricity demand. 
Although the rural electrification scheme did not show significant differences between grid extension and solar systems, there might be long-term effects of the SHS and the hybrid system not considered in our analysis, for example, problems arising from system management and maintenance, as well as post-operation waste management. Increasing available energy by SHS is also a big issue. All of these aspects are interesting and important to consider in more comprehensive studies on the implications of the selection of the electrification scheme.

Finally, we should note that this article primarily analysed the short-term effects, suggesting that a future study on longer-term effects is needed. Regardless of the moderate amount of short-term positive effects observed to date, periodic surveys will still be continued in the future to evaluate the long-term effects and longitudinal changes that electrification yields on rural communities. Different electrification schemes could also make substantial changes in the long-term. All of these constitute a fertile ground for future studies.

\section{Conclusions}

This article has analysed the impacts of electrification by different systems on QoL in Southeast Asian villages using subjective well-being measurements. Four villages typical of Southeast Asia were selected for the study and original data were surveyed to create a baseline prior electrification and an endpoint afterward to be used for comparison. From the graphical and statistical analyses, it was confirmed that self-reported QoL as well as psychological, physical, and social well-being levels increased after electrification. In contrast, a certain reduction in economic well-being levels was also observed, hypothesised to have a correlation with no increase on productive activities and a decline in available household budget. For the analysed QoL sub-domains, there were no changes after electrification on satisfaction levels with time use, time spent alone, housing, and personal safety, and a positive effect on satisfaction levels with cooking. Moreover, in terms of occupation, no changes in the total hours dedicated to work and no prolonged active time on usual activities in the household were observed. Overall, the findings provide support to the hypothesis of a positive effect on QoL from electrification, but they also detail a more precise description of the effect on specific QoL dimensions, which clarifies facts presumed by indirect economic or aggregated measures.

Other perspectives have been discussed in light of these findings. First, from a socio-cultural theory lens, our analysis seems to attest to how electrification associates with a shift in needs, directing preferences for household equipment associated with new energy services and the dynamics stated in the energy services ladder hypothesis. Second, from a technological systems viewpoint, the rural electrification scheme did not show important differences between systems beyond the prices paid for electricity, which were in general higher for the grid and centralised hybrid systems over the SHS. Problems arising from system management and maintenance, as well as post-operation waste management, might later become an issue, but all of these aspects are fertile ground for future studies. The findings comprise effects from a one-year perspective and longer-span analyses are needed to complement them.

The main contribution of the present study is a direct approximation of the effects of electrification schemes on QoL in Southeast Asia, and pioneering results for the explicit connection between electrification and human well-being.

Author Contributions: J.C., H.O., C.T. conceptualised this article; C.T., H.S.C., H.T., B.L., E.O., H.O. and J.C. carried out all data collection; J.C., H.S.C., S.K., and H.F. designed the methodological approach; Data analysis was carried out by J.C., H.O., H.S.C., C.T.; Writing by J.C., C.T., H.S.C., and H.O.; Review and editing by C.T., H.S.C., N.A.R., H.T., B.L., E.O., H.F., H.O. and J.C.; and project administration, supervision and resources provided by H.O. and N.A.R. All authors have read and agreed to the published version of the manuscript.

Funding: This research was partially funded by Japan-ASEAN Science, Technology and Innovation Platform (JASTIP), the Kurata Grant (awarded by the Hitachi Global Foundation) [Grant No 1359], ZE collaborative research at The Institute of Advanced Energy, Kyoto University, Japan, as well as the "Rural Electrification-Ensuring Long Term Sustainability Through Community Aligned Renewables Empowerment (CARE)" Grant [Grant No. RU013-2017Z] from The University of Malaya, Malaysia. 
Acknowledgments: We would like to thank students and staff from UMPEDAC in University of Malaya, ITC, UY, and PU for help with the local interview sessions, as well as Randy Muth for his proof-reviewing of the article and three anonymus reviewers helping to improve the quality of its content.

Conflicts of Interest: The authors declare no conflict of interest.

\section{References}

1. WB. Sustainable Energy for All Global Tracking Framework; The World Bank: Washington, DC, USA, 2019. Available online: https://www.worldbank.org/en/topic/energy/publication/Global-Tracking-FrameworkReport (accessed on 15 March 2020).

2. WEO IEA. Special Report: Energy Access Outlook; IEA WEO: Paris, France, 2017.

3. Chatterjee, A.; Burmester, D.; Brent, A.; Rayudu, R. Research Insights and Knowledge Headways for Developing Remote, Off-Grid Microgrids in Developing Countries. Energies 2019, 12, 2008. [CrossRef]

4. Quintero Pulido, D.F.; Ten Kortenaar, M.V.; Hurink, J.L.; Smit, G.J.M. The Role of Off-Grid Houses in the Energy Transition with a Case Study in the Netherlands. Energies 2019, 12, 2033. [CrossRef]

5. Mandal, S.; Das, B.K.; Hoque, N. Optimum sizing of a stand-alone hybrid energy system for rural electrification in Bangladesh. J. Clean. Prod. 2018, 200, 12-27. [CrossRef]

6. Barman, M.; Mahapatra, S.; Palit, D.; Chaudhury, M.K. Performance and impact evaluation of solar home lighting systems on the rural livelihood in Assam, India. Energy Sustain. Dev. 2017, 38, 10-20. [CrossRef]

7. Mazzola, S.; Astolfi, M.; Macchi, E. The potential role of solid biomass for rural electrification: A techno economic analysis for a hybrid microgrid in India. Appl. Energy 2016, 169, 370-383. [CrossRef]

8. Smith, C.; Burrows, J.; Scheier, E.; Young, A.; Smith, J.; Young, T.; Gheewala, S.H. Comparative Life Cycle Assessment of a Thai Island's diesel/PV/wind hybrid microgrid. Renew. Energy 2015, 80, 85-100. [CrossRef]

9. Ismail, M.S.; Moghavvemi, M.; Mahlia, T.M.I. Techno-economic analysis of an optimized photovoltaic and diesel generator hybrid power system for remote houses in a tropical climate. Energy Convers. Manag. 2013, 69, 163-173. [CrossRef]

10. Radzi, M.A.M.; Rahim, N.A.; Che, H.S.; Ohgaki, H.; Farzaneh, H.; Wong, W.S.H.; Hung, L.C. Optimal solar powered system for long houses in sarawak by using homer tool. Asean Eng. J. 2019, 9, 1-14.

11. Ciller, P.; Lumbreras, S. Electricity for all: The contribution of large-scale planning tools to the energy-access problem. Renew. Sustain. Energy Rev. 2020, 120, 109624. [CrossRef]

12. Batinge, B.; Kaviti Musango, J.; Brent, A.C. Perpetuating energy poverty: Assessing roadmaps for universal energy access in unmet African electricity markets. Energy Res. Soc. Sci. 2019, 55, 1-13. [CrossRef]

13. Nathwani, J.; Kammen, D.M. Affordable Energy for Humanity: A Global Movement to Support Universal Clean Energy Access. Proc. IEEE 2019, 107, 1780-1789. [CrossRef]

14. Malakar, Y. Evaluating the role of rural electrification in expanding people's capabilities in India. Energy Policy 2018, 114, 492-498. [CrossRef]

15. Aglina, M.K.; Agbejule, A.; Nyamuame, G.Y. Policy framework on energy access and key development indicators: ECOWAS interventions and the case of Ghana. Energy Policy 2016, 97, 332-342. [CrossRef]

16. Palit, D.; Bandyopadhyay, K.R. Rural electricity access in South Asia: Is grid extension the remedy? A critical review. Renew. Sustain. Energy Rev. 2016, 60, 1505-1515. [CrossRef]

17. Urmee, T.; Md, A. Social, cultural and political dimensions of off-grid renewable energy programs in developing countries. Renew. Energy 2016, 93, 159-167. [CrossRef]

18. Boliko, C.M.; Ialnazov, D.S. An assessment of rural electrification projects in Kenya using a sustainability framework. Energy Policy 2019, 133, 110928. [CrossRef]

19. Winther, T.; Ulsrud, K.; Matinga, M.; Govindan, M.; Gill, B.; Saini, A.; Brahmachari, D.; Palit, D.; Murali, R. In the light of what we cannot see: Exploring the interconnections between gender and electricity access. Energy Res. Soc. Sci. 2020, 60, 101334. [CrossRef]

20. Tesfamichael, M.; Bastille, C.; Leach, M. Eager to connect, cautious to consume: An integrated view of the drivers and motivations for electricity consumption among rural households in Kenya. Energy Res. Soc. Sci. 2020, 63, 101394. [CrossRef]

21. Zhang, G.; Li, K.; Gu, D.; Wang, X.; Yang, X.; Zhu, K.; Liang, G. Visualizing Knowledge Evolution and Hotspots of Rural Environment and Health: A Systematic Review and Research Direction. IEEE Access 2019, 7, 72538-72550. [CrossRef] 
22. Pasten, C.; Santamarina, J.C. Energy and quality of life. Energy Policy 2012, 49, 468-476. [CrossRef]

23. An, I.E.G. The Welfare Impact of Rural Electrification: A Reassessment of the Costs and Benefits; Technical Report; World Bank: Washington, DC, USA, 2008.

24. Barnes, D.F. Electric Power for Rural Growth: How Electricity Affects Rural Life in Developing Countries, 2nd ed.; Routledge: Abingdon-on-Thames, UK, 2019.

25. Lemaire, X. Solar home systems and solar lanterns in rural areas of the Global South: What impact? Wiley Interdiscip. Rev. Energy Environ. 2018, 7, e301. [CrossRef]

26. Bilich, A.; Langham, K.; Geyer, R.; Goyal, L.; Hansen, J.; Krishnan, A.; Bergesen, J.; Sinha, P. Life Cycle Assessment of Solar Photovoltaic Microgrid Systems in Off-Grid Communities. Environ. Sci. Technol. 2017, 51, 1043-1052. [CrossRef] [PubMed]

27. Nadimi, R.; Tokimatsu, K. Modeling of quality of life in terms of energy and electricity consumption. Appl. Energy 2018, 212, 1282-1294. [CrossRef]

28. Kahneman, D.; Diener, E.; Schwarz, N. Well-Being: Foundations of Hedonic Psychology; Russell Sage Foundation: New York, NY, USA, 1999.

29. OECD. OECD Guidelines on Measuring Subjective Well-Being; OECD: Paris, France, 2013; ISBN 9789264191648.

30. Ostenfeld, E. Aristotle on the good life and quality of life. In Concepts and Measurement of Quality of Life in Health Care; Springer: Berlin/Heidelberg, Germany, 1994; pp. 19-34.

31. Burckhardt, C.S.; Anderson, K.L. The Quality of Life Scale (QOLS): Reliability, validity, and utilization. Health Qual. Life Outcomes 2003, 1, 60. [CrossRef]

32. Diamond, R.; Becker, M.; Becker, R. Wisconsin Quality of Life Index (W-QLI): A Multidimensional Model for Measuring Quality of Life. J. Clin. Psychiatry 1999, 60, 29-31. [PubMed]

33. Shallo, L.; Ayele, M.; Sime, G. Determinants of biogas technology adoption in southern Ethiopia. Energy Sustain. Soc. 2020, 10. [CrossRef]

34. Crentsil, A.O.; Asuman, D.; Fenny, A.P. Assessing the determinants and drivers of multidimensional energy poverty in Ghana. Energy Policy 2019, 133, 110884. [CrossRef]

35. Dang, D.A.; La, H.A. Does electricity reliability matter? Evidence from rural Viet Nam. Energy Policy 2019, 131, 399-409. [CrossRef]

36. Mishra, P.; Behera, B. Socio-economic and environmental implications of solar electrification: Experience of rural Odisha. Renew. Sustain. Energy Rev. 2016, 56, 953-964. [CrossRef]

37. Halder, P.K. Potential and economic feasibility of solar home systems implementation in Bangladesh. Renew. Sustain. Energy Rev. 2016, 65, 568-576. [CrossRef]

38. Bridge, B.A.; Adhikari, D.; Fontenla, M. Electricity, income, and quality of life. Soc. Sci. J. 2016, 53, 33-39. [CrossRef]

39. Bensch, G.; Kluve, J.; Peters, J. Impacts of rural electrification in Rwanda. J. Dev. Eff. 2011, 3, 567-588. [CrossRef]

40. Oxford-Analytica. Uneven Electrification Will Affect ASEAN Competition; Oxford Analytica Daily Brief: 2017. Available online: https://dailybrief.oxan.com/Analysis/GA220581/Uneven-electrification-will-affectASEAN-competition (accessed on 15 March 2020).

41. Phoumin, H.; Kimura, S.; Abdurrahman, S.; Sirikum, J.; Manaligod, L.R.A.; Zulkifli, Z. Distributed Energy System in Southeast Asia; Economic Research Institute for ASEAN and East Asia (ERIA): Jakarta, Indonesia, 2018.

42. Saing, C.H. Rural electrification in Cambodia: Does it improve the welfare of households? Oxf. Dev. Stud. 2018, 46, 147-163. [CrossRef]

43. Martin, S.; Susanto, J. Supplying power to remote villages in Lao PDR.-The role of off-grid decentralised energy options11This paper is an adapted and updated version of a paper initially presented at the International Conference: Know your Power, organized by MEE NET on 18-19. Energy Sustain. Dev. 2014, 19, 111-121. [CrossRef]

44. Bambawale, M.J.; D’Agostino, A.L.; Sovacool, B.K. Realizing rural electrification in Southeast Asia: Lessons from Laos. Energy Sustain. Dev. 2011, 15, 41-48. [CrossRef]

45. Ölz, S.; Beerepoot, M. Deploying Renewables in Southeast Asia. In IEA Energy Papers; OECD Publishing: Paris, France, 2010. [CrossRef]

46. Ajan, C.W. Delivering Sustainable Energy: Foundation to Low Carbon, Economy Sustainability Report 2018; Sarawak Energy; p. 63. Available online: https://www.sarawakenergy.com/assets/pdf/sustainability-reports/ seb-sr2018.pdf (accessed on 15 March 2020). 
47. Ohgaki, H.; Farzaneh, H.; Rahim, N.A.; Che, H.S.; Radzi, M.A.M.; Wong, W.; Hung, L.C. Study on Quality of Life Change for Rural Community through Rural Electrification by Renewable Energy: Preliminary Result. ASEAN J. Manag. Innov. 2015, 4, 1-8.

48. EDC. Program For the Development of Rural Electrification of Department of Rural Electrification Fund Electricité Du Cambodge (REF); Electricité Du Cambodge, Department of Rural Electrification, 2013. Available online: https://policy.asiapacificenergy.org/node/333 (accessed on 15 March 2020).

49. Dave, R.; Keller, S.; Koo, B.; Fleurantin, G.; Portale, E.; Rysankova, D. Cambodia Beyond Connections: Energy Access Diagnostic Report Based on the Multi-Tier Framework (English); 124490; The World Bank, 2018; Available online: http://documents.worldbank.org/curated/en/141011521693254478/Cambodia-Beyond-connectionsenergy-access-diagnostic-report-based-on-the-multi-tier-framework (accessed on 15 March 2020).

50. EDC. Annual Report 2017; Electricite du Cambodge. Available online: http:/www.edc.com.kh/images/ Annual\%20Report\%202017\%20(English)_.pdf (accessed on 15 March 2020).

51. EAC. Annual Report 2018; Electricity Authority of Cambodia: Phnom Penh, Cambodia, 2018.

52. WB. Myanmar National Electrification Project: Environmental Assessment: Environmental and Social Management Framework (English); SFG1132; The World Bank: Myanmar, 2018. Available online: http://documents. worldbank.org/curated/en/224731468274160604/Environmental-and-social-management-framework (accessed on 15 March 2020).

53. Creswell, J.W.; Creswell, J.D. Research Design: Qualitative, Quantitative, and Mixed Methods Approaches; Sage Publications: New York, NY, USA, 2017.

54. Bernard, H.R. Research Methods in Anthropology: Qualitative and Quantitative Approaches; Rowman \& Littlefield: Lanham, MD, USA, 2017.

55. Caron, J.; Corbière, M.; Mercier, C.; Diaz, P.; Ricard, N.; Lesage, A. The construct validity of the client questionnaire of the Wisconsin Quality of Life Index A cross-validation study. Int. J. Methods Psychiatr. Res. 2003, 12, 128-138. [CrossRef] [PubMed]

56. Winther, T.; Ulsrud, K.; Saini, A. Solar powered electricity access: Implications for women's empowerment in rural Kenya. Energy Res. Soc. Sci. 2018, 44, 61-74. [CrossRef]

57. Khandker, S.R.; Samad, H.A.; Ali, R.; Barnes, D.F. Who benefits most from rural electrification? Evidence in India. Energy J. 2014, 35, 75-96. [CrossRef]

58. Richmond, J.; Urpelainen, J. Electrification and appliance ownership over time: Evidence from rural India. Energy Policy 2019, 133. [CrossRef]

59. Den Heeten, T.; Narayan, N.; Diehl, J.C.; Verschelling, J.; Silvester, S.; Popovic-Gerber, J.; Bauer, P.; Zeman, M. Understanding the Present and the Future Electricity Needs: Consequences for Design of Future Solar Home Systems for Off-Grid Rural Electrification. In Proceedings of the 2017 Twenty Fifth International Conference on the Domestic Use of Energy (Due), Cape Town, South Africa, 4-5 April 2017; pp. 8-15.

60. Sirgy, M.J. Towards a New Concept of Residential Well-Being Based on Bottom-Up Spillover and Need Hierarchy Theories; Veenhoven, R., Ed.; Springer International Publishing Switzerland: Cham, Switzerland, 2016; pp. 131-150. [CrossRef]

61. Kabir, E.; Kim, K.H.; Szulejko, J.E. Social impacts of solar home systems in rural areas: A case study in Bangladesh. Energies 2017, 10, 1615. [CrossRef]

62. Hirmer, S.; Guthrie, P. Identifying the needs of communities in rural Uganda: A method for determining the 'User-Perceived Value' of rural electrification initiatives. Renew. Sustain. Energy Rev. 2016, 66, 476-486. [CrossRef]

63. Cabraal, R.A.; Barnes, D.F.; Agarwal, S.G. Productive Uses of Energy for Rural Development. Annu. Rev. Environ. Resour. 2005, 30, 117-144. [CrossRef]

64. Cecelski, E. Energy, Poverty, and Gender; World Bank: Washington, DC, USA, 2003.

65. Idris, K.; Shaffril, H.A.M.; Yassin, S.M.; Samah, A.A.; Hamzah, A.; Samah, B.A. Quality of life in rural communities: Residents living near to Tembeling, Pahang and Muar Rivers, Malaysia. PLoS ONE 2016, 11, 1-16. [CrossRef] [PubMed]

66. Parikh, P.; Chaturvedi, S.; George, G. Empowering change: The effects of energy provision on individual aspirations in slum communities. Energy Policy 2012, 50, 477-485. [CrossRef]

67. Diener, E.; Oishi, S.; Tay, L. Advances in subjective well-being research. Nat. Hum. Behav. 2018, 2, 253-260. [CrossRef]

68. Potter, J.; Cantarero, R.; Wood, H. The Multi-Dimensional Nature of Predicting Quality of Life. Procedia. Soc. Behav. Sci. 2012, 50, 781-790. [CrossRef] 
69. Riva, F.; Ahlborg, H.; Hartvigsson, E.; Pachauri, S.; Colombo, E. Electricity access and rural development: Review of complex socio-economic dynamics and causal diagrams for more appropriate energy modelling. Energy Sustain. Dev. 2018, 43, 203-223. [CrossRef]

70. Al-faruq, U.; Sagala, S.; Rianawati, E.; Currie, E. Assessment of Renewable Energy Impact to Community Resilience in Sumba Island; Working Paper No. 9. Resilience Development Initiative: Bandung, Indonesia, 2016. Available online: https://www.rdi.or.id/file/pdf/78.pdf (accessed on 15 March 2020).

71. Imai, K.; Palit, D. Impacts of Electrification with Renewable Energies on Local Economies: The Case of India's Rural Areas. Agi. Work. Pap. Ser. 2013, 2013-2, 1-21.

72. Dinkelman, T. The Effects of Rural Electrification on Employment: New Evidence from South Africa. Am. Econ. Rev. 2011, 101, 3078-3108. [CrossRef]

73. Arráiz, I.; Calero, C. From Candles to Light: The Impact of Rural Electrification; IDB Working Paper Series, No. IDB-WP-599; Inter-American Development Bank (IDB): Washington, DC, USA, 2015.

74. Sinha, S. In Pursuit of a Light Bulb and a Smokeless Kitchen: Longitudinal Analysis of the Role of Energy Sector Policies to Alleviate Rural Energy Poverty in India. Ph.D. Thesis, University of Twente, Enschede, The Netherland, December 2012.

75. Clancy, J.S.; Skutsch, M.; Batchelor, S. The Gender-Energy-Poverty Nexus: Finding the Energy to Address Gender Concerns in Development. Project Report. Available online: https:/www.cleancookingalliance.org/resources/ 300.html (accessed on 15 March 2020).

76. Kooijman-van Dijk, A.L.; Clancy, J. Impacts of Electricity Access to Rural Enterprises in Bolivia, Tanzania and Vietnam. Energy Sustain. Dev. 2010, 14, 14-21. [CrossRef]

77. WB. Global Consumption Database, Cambodia; The World Bank Global Development Database. Available online: http://datatopics.worldbank.org/consumption/country/Cambodia (accessed on 7 April 2019).

78. Cravioto, J.; Yamasue, E. Energy services and life satisfaction: A study on households in two Mexican communities. In Proceedings of the Energy for Society: 1st International Conference on Energy Research \& Social Science, Barcelona, Spain, 2 April 2017. [CrossRef]

79. Cravioto, J.; Yamasue, E.; Okumura, H.; Ishihara, K.N. Energy service satisfaction in two Mexican communities: A study on demographic, household, equipment and energy related predictors. Energy Policy 2014, 73, 110-126. [CrossRef]

80. Sovacool, B.K.; Mukherjee, I. Conceptualizing and measuring energy security: A synthesized approach. Energy 2011, 36, 5343-5355. [CrossRef]

81. Winther, T. Rising electricity consumption: Driving forces and consequences. The case of rural Zanzibar. In Proceedings of the ECEEE Conference 2007, Panel 9 "Dynamics of Consumption", Nice, France, 4-9 June 2007; pp. 1835-1845.

82. Clancy, J.S.; Winther, T.; Matinga, M.N.; Oparaocha, S. Gender Equity in Access to and Benefits from Modern Energy and Improved Energy Technologies. ETC/ENERGIA in Association Nord/Sør-konsulentene. 2012. Available online: https://research.utwente.nl/en/publications/gender-equity-in-access-to-and-benefits-frommodern-energy-and-im (accessed on 11 May 2020).

83. Winther, T.; Saini, A.; Ulsrud, K.; Govindan, M.; Gill, B.; Matinga, M.N.; Palit, D.; Brahmachari, D.; Murali, R.; Gichungi, H. Women's Empowerment and Electricity Access: How do Grid and Off-Grid Systems Enhance or Restrict Gender Equality? ENERGIA International Network on Gender \& Sustainable Energy: The Hague, The Netherlands, 2019. Available online: https://www.energia.org/cm2/wp-content/uploads/2019/04/RA1Womens-empowerment-and-electricity-access.pdf (accessed on 11 May 2020).

(C) 2020 by the authors. Licensee MDPI, Basel, Switzerland. This article is an open access article distributed under the terms and conditions of the Creative Commons Attribution (CC BY) license (http://creativecommons.org/licenses/by/4.0/). 